\title{
Connected Mental Health: Systematic Mapping Study
}

Nidal Drissi ${ }^{1,2}$, MSc; Sofia Ouhbi ${ }^{1}, \mathrm{PhD}$; Mohammed Abdou Janati Idrissi ${ }^{2}, \mathrm{PhD}$; Luis Fernandez-Luque ${ }^{3,4}, \mathrm{PhD}$; Mounir Ghogho ${ }^{5}, \mathrm{PhD}$

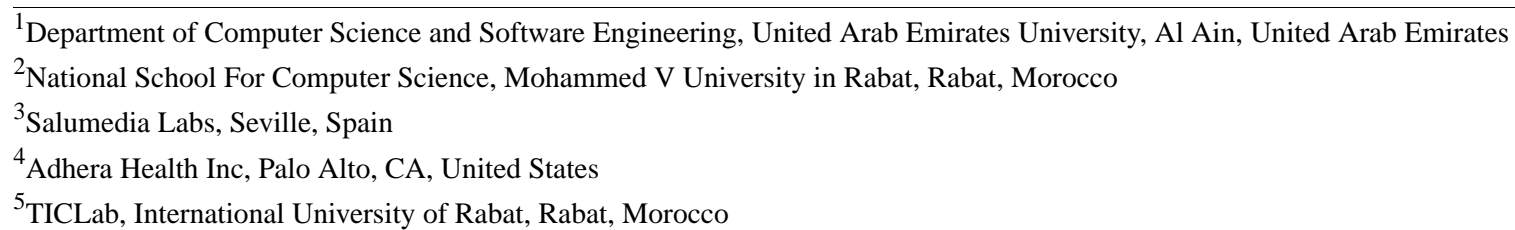

${ }^{5}$ TICLab, International University of Rabat, Rabat, Morocco

\section{Corresponding Author:}

Sofia Ouhbi, $\mathrm{PhD}$

Department of Computer Science and Software Engineering

United Arab Emirates University

College of Information Technology, United Arab Emirates University

Al Ain, 15551

United Arab Emirates

Phone: 97137135568

Email: sofia.ouhbi@uaeu.ac.ae

\section{Abstract}

Background: Although mental health issues constitute an increasing global burden affecting a large number of people, the mental health care industry is still facing several care delivery barriers such as stigma, education, and cost. Connected mental health $(\mathrm{CMH})$, which refers to the use of information and communication technologies in mental health care, can assist in overcoming these barriers.

Objective: The aim of this systematic mapping study is to provide an overview and a structured understanding of CMH literature available in the Scopus database.

Methods: A total of 289 selected publications were analyzed based on 8 classification criteria: publication year, publication source, research type, contribution type, empirical type, mental health issues, targeted cohort groups, and countries where the empirically evaluated studies were conducted.

Results: The results showed that there was an increasing interest in $\mathrm{CMH}$ publications; journals were the main publication channels of the selected papers; exploratory research was the dominant research type; advantages and challenges of the use of technology for mental health care were the most investigated subjects; most of the selected studies had not been evaluated empirically; depression and anxiety were the most addressed mental disorders; young people were the most targeted cohort groups in the selected publications; and Australia, followed by the United States, was the country where most empirically evaluated studies were conducted.

Conclusions: $\mathrm{CMH}$ is a promising research field to present novel approaches to assist in the management, treatment, and diagnosis of mental health issues that can help overcome existing mental health care delivery barriers. Future research should be shifted toward providing evidence-based studies to examine the effectiveness of CMH solutions and identify related issues.

(J Med Internet Res 2020;22(8):e19950) doi: $\underline{10.2196 / 19950}$

\section{KEYWORDS}

mental health; connected health; eHealth; mobile health; telehealth; mHealth; mobile phone; health informatics; review; interdisciplinary research; information technology; information systems 


\section{Introduction}

\section{Background}

Mental health issues can decrease the quality of life [1,2], increase the risk of communicable and noncommunicable diseases, and contribute to both unintentional and intentional injury [3]. They may also cause, among other issues, lower educational achievements, substance abuse, and violence [4]. Mental illness is considered as "one of the main causes of unhappiness in the world. It produces nearly as much of the misery that exists as poverty does, and more than is caused by physical illness" [5]. On average, they reduce national income by $5 \%$ through unemployment, absenteeism, lowered productivity, and extra physical health care costs [6].

Although mental health issues constitute a global concern and threat, the mental health care industry is still struggling to overcome various barriers and reach people in need [7]. In lowand middle-income countries, more than $75 \%$ of people identified with serious anxiety, problematic mood changes, impulse control, or substance abuse disorders did not receive any care [8]. Among the barriers and challenges that threaten the mental health care industry are cost issues [9], shortage of mental health care providers, health plan barriers, lack of coverage or inadequate coverage [10], stigma, and poor mental health literacy [11]. Cultural orientations can, in some cases, be considered as a barrier for seeking mental help and access [12]. Mental health care delivery can also face barriers in complicated situations such as the recent coronavirus disease (COVID-19) global outbreak [13,14]. Such pandemics create global feelings of fear, worry, sadness, and anger and cause a global increase in stress and anxiety, especially for people with existing mental health problems $[15,16]$, putting more load on health care institutions. They also create new obstacles to mental health care delivery as many people are in quarantine and several countries are in complete lockdown, making access to mental health care even more challenging [17].

Connected mental health $(\mathrm{CMH})$, which refers to the use of information and communication technologies (ICT) to support and improve mental health conditions and mental health care, can help alleviate some of the aforementioned barriers [18]. This presents unlimited possibilities and opportunities to help overcome the challenges, barriers, and limitations of the mental health care industry [18].

$\mathrm{CMH}$ solutions are connected health solutions for mental health care. The term connected health is used to "encompass terms such as wireless, digital, electronic, mobile, and tele-health" [19]. Connected health has become an established research field in the past 5 years [20]. In this paper, we use the term CMH to refer to topics related to electronic mental (e-mental) health, mobile mental (m-mental) health, telemental health, and digital mental health, among others. CMH solutions have the potential to allow anonymous access to overcome care preventing stigma, access to care with minimal to no cost, reach remote areas, enhance patients' engagement, and access information [21,22]. They also have the potential to deliver cost-effective mental health services [23]; overcome geographical barriers [24]; and provide a better understanding of mental illnesses' development, recovery, symptom assessment, and monitoring through the use of technology [25]. CMH can use technology-based interventions such as video conferencing; telemental health [26]; mobile-based interventions [27,28]; internet-based solutions [29,30], which are necessary in situations such as global health pandemics; and novel digital data collection interventions [31,32]. In addition, $\mathrm{CMH}$ can improve several important areas of mental health care, including primarily information provision, screening, assessment, monitoring, intervention, and social support [22].

\section{Objectives}

This paper presents the results of a systematic mapping study conducted to analyze the current research landscape of $\mathrm{CMH}$ literature in the Scopus database. To conduct the analysis, 8 mapping questions (MQs) were addressed, which allowed us to classify 289 selected publications indexed in Scopus according to their publication year, publication source, research type, contribution, empirical type, mental health issues, and targeted cohort.

\section{Methods}

\section{Overview}

This study follows the mapping process proposed by Petersen et al [33]. This process covers the selection of relevant publications, the construction of a classification scheme, and a systematic mapping of publications. The principal objective of a systematic mapping study is to structure a research area and provide an overview of the available literature, primarily by investigating the covered topics and classifying the available contributions [34].

\section{MQs}

Textbox 1 presents the $8 \mathrm{MQs}$ and their rationale. The MQs were defined to provide an overview and a structured understanding of the existing $\mathrm{CMH}$ literature in the Scopus database. 
Textbox 1. Mapping questions.

MQ1 (mapping question)

- How has the frequency of publications addressing $\mathrm{CMH}$ (connected mental health) changed over time?

MQ2

- Which publication channels are the main target for $\mathrm{CMH}$ research?

MQ3

- What are the research types of studies addressing $\mathrm{CMH}$ ?

MQ4

- What are the contributions of published CMH studies?

MQ5

- Are CMH studies empirically validated or evaluated?

MQ6

- What are the mental health disorders addressed in $\mathrm{CMH}$ literature?

MQ7

- Who are the target audience in CMH studies?

MQ8

- In which countries were the selected empirically evaluated studies conducted?

\section{Search Strategy}

The search was conducted in the Scopus database, which is considered to be the largest indexation database that includes articles from various disciplines such as engineering, medicine, business, and computer science [35].

The aim of the selection process was to identify the articles that are most relevant to the objective of this mapping study. To further focus the search and include relevant studies, the search was focused on the titles of the publications.

The following search strings were applied to the titles of the publications indexed in Scopus:

- "e-" AND "mental" AND "health"

- ("Mobile" OR "M-") AND "mental" AND "health"

- "Digital" AND "mental" AND "health"

- "Connected" AND "mental" AND "health"

- "Tele" AND "mental" AND "health"

The search strings were formulated to include a broad selection of literature and were not combined in one search string for the purpose of identifying the number of results for each term separately. The search for publications was conducted on January 23, 2020.

\section{Papers Selection}

The first author (ND) retrieved candidate papers from the results of the search and entered information in an Excel (Microsoft
Corporation) file that was shared with the second author (SO) for revision. The two authors examined the title, abstract, and keywords and then commented on whether the paper was to be included in or excluded from the selection according to the inclusion and exclusion criteria (EC).

The inclusion criterion was limited to publications that addressed an aspect of $\mathrm{CMH}$, and the studies that satisfied any one of the following EC were eliminated:

- EC1: studies published after 2019 to construct a clear trend of publication

- EC2: studies not published in English, as there is a clear dominance of the English language in the international communications, science, and literature [36,37]

- EC3: papers published as notes, editorials, or letters

- EC4: publications not addressing mental health issues

- EC5: publications not addressing the use of technology for mental health.

Figure 1 shows the selection results. A total of 289 papers (out of 571 candidate studies) were included in the final selection. EC 1, 2, and 3 were applied in the Excel file. Checking for EC 4 and 5 and the screening of studies were conducted by inspecting the abstracts and, in some cases, the full texts of the candidate studies. 
Figure 1. Selection process. EC: exclusion criteria; e-mental: electronic mental; tele-mental health: telehealth for mental health.
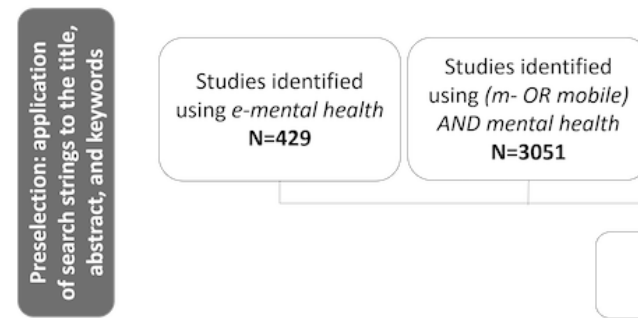
$\mathrm{N}=\mathbf{3 0 5 1}$
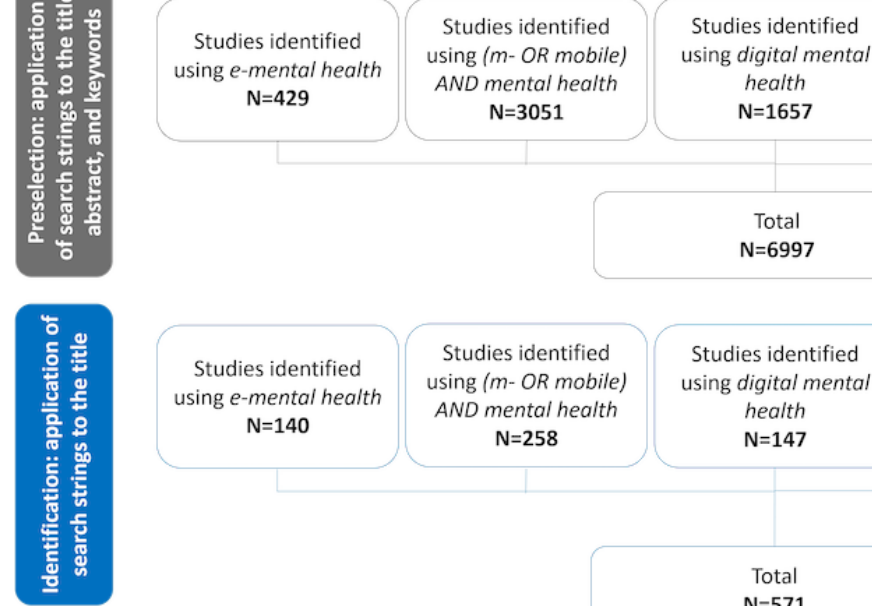

Studies identified using ( $m$-OR mobile) AND mental health $\mathrm{N}=\mathbf{2 5 8}$

Studies identified using digital mental health $\mathrm{N}=147$

\section{Total}

$$
\mathrm{N}=140
$$

\section{Studies identified using connected mental heaith $\mathrm{N}=16$}

Studies identified using tele-mental health $\mathrm{N}=10$
Application of EC1, EC2, and EC3

EC1: papers excluded: $\mathrm{N}=11$ EC2: papers excluded: $\mathrm{N}=52$

EC3: papers excluded: $\mathrm{N}=61$ Total excluded papers $\mathrm{N}=124$
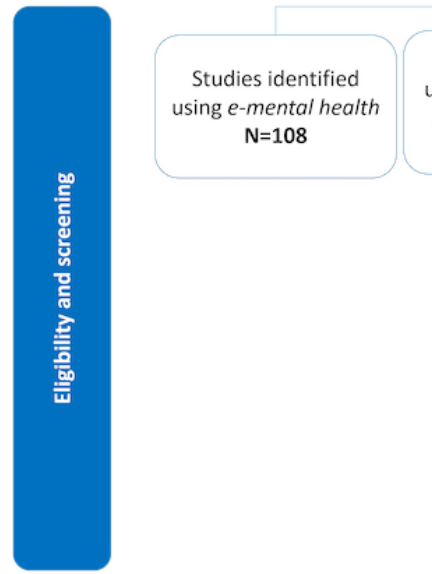

Studies identified using digital mental health $\mathrm{N}=117$
Studies identified using connected mental health $\mathrm{N}=13$
Studies identified using tele-mental health $\mathrm{N}=8$

\section{Data Extraction Strategy}

The extraction of data from the selected studies was focused primarily on providing answers to the MQs according to the criteria presented in Textbox 2 . 
Textbox 2. Classification criteria.

MQ1 (mapping question)

- Identifying the publication year and term used can assist in suggesting the publication trend. The main term of each study was not based on the results of the selection process but was based on an analysis of the content of the publications

MQ2

- Identifying the publication channel and the publication source of each study

MQ3

- Research types can be classified as follows: (1) solution proposal: a solution to an existing problem, either novel solution or a significant extension of an existing solution; (2) review: analysis of the existing literature; (3) exploratory study: conducting research and investigating on a specific aspect; (4) opinion paper: these papers express the personal opinion of the author on a specific technique not relying on related work or research methodologies; (5) validation research: this type of paper investigates novel solutions that have not been implemented yet; (6) evaluation research: conducting a study on an implemented solution by identifying how the solution has been implemented in practice, the benefits and drawbacks of the implementation, and relevant problems in the field; (7) feasibility study: an analysis of relevant factors of success of an intervention to determine the likelihood of its implementation successfully; and (8) books and book chapters

MQ4

- The contributions of the selected studies can be classified as follows: (1) tool-based techniques: techniques based on software or devices used to accomplish a connected mental health (CMH)-related task; (2) model: a system that allows structured utilization of CMH solutions; (3) method: development or design of an approach by creating a series of steps that can assist in utilizing CMH solutions; (4) guidelines: a set of rules or recommendations to be followed during the course of an action related to $\mathrm{CMH} ;(5)$ framework: a real or conceptual structure intended to support and guide the creation of CMH-related contributions; (6) protocol: a set of rules guiding use of technology for mental health care; (7) perspectives and attitudes toward CMH: results on perspectives, attitudes, acceptance, and preferences toward CMH in general or in a specific group of people; (8) advantages and challenges of CMH: views regarding the advantages, benefits, risks, challenges, and limitations of CMH; and (9) other: results of general research on the efficacy, effectiveness, and usability of $\mathrm{CMH}$ interventions

MQ5

- The empirical types can be classified as follows: (1) experiment: testing a hypothesis by creating a situation with controlled conditions; (2) case study: testing a solution in real life, with the purpose of gathering new information and detecting potential issues by analyzing real cases; (3) questionnaire: a set of specific, easy to answer questions targeting an audience to collect large amounts of data; (4) interview: a conversational method based on asking specific questions to gather in-depth, precise, and meaningful data; (5) mixed methods: using more than one empirical evaluation method; (6) focus group: investigating results and feedback in a relatively small group of participants; (7) other: all empirical evaluation methods that do not belong to any of the categories above; and (8) none: all solutions that were not validated empirically were classified as theories

MQ6

- Identifying the mental problem addressed in each study

MQ7

- Identifying the targeted cohort group

MQ8

- Identifying the country or region where the study has been conducted. Nonempirically evaluated studies are usually general, whereas empirically evaluated studies focus on specific groups and countries or regions. Therefore, for this question, we focus on the latest

\section{Synthesis Method}

The synthesis method used in this study consisted of the following steps:

- $\quad$ Reading and analyzing the 289 selected studies to extract information presented in the Data Extraction Strategy subsection.

- Classifying the studies by enumerating the number of publications per MQ. It should be noted that selected publications addressing more than one mental health issue (MQ6), more than one cohort group (MQ7), and more than one country (MQ8) were counted in each category.
- Presenting the classification results in figures and charts, such as bubble plots, as visualization of the results facilitated their analysis.

- Presenting a narrative summary to describe the principal findings.

\section{Compliance With Ethical Standards}

This paper does not contain any study with human participants or animals.

\section{Results}

This section summarizes the results of the MQs. The results of the mapping study can be found in Multimedia Appendix 1 . 


\section{MQ1: How Has the Frequency of Publications Addressing CMH Changed Over Time?}

Figure 2 shows the publication trend per term used in the selected papers: mobile or m-mental, e-mental, digital, and telemental health. This shows a significant increase in interest in the field of $\mathrm{CMH}$ research in the past decade. The publication trend began with fewer than 5 publications per year until 2011. We estimate that the trend of publication will continue to increase in 2020, particularly owing to the increasing interest in mental health during the recent COVID-19 pandemic.

Figure 2. Connected mental health publication trend. e-mental: electronic mental; tele-mental health: telehealth for mental health.

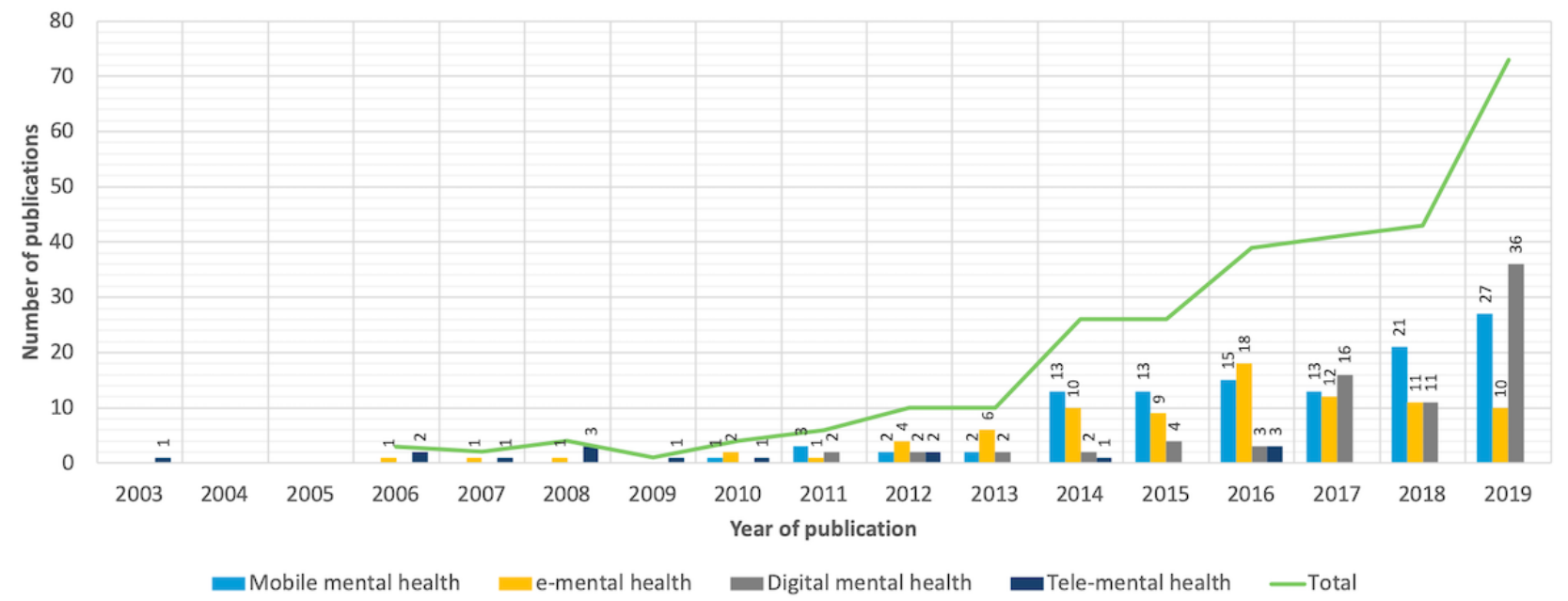

\section{MQ2: Which Publication Channels Are the Main Target for CMH Research?}

A total of 3 publication channels have been identified from the selected studies: journals, conferences, and books. Overall, $82.3 \%(238 / 289)$ of the selected papers were published in journals, $11.4 \%(33 / 289)$ were published in conference proceedings, and $6.2 \%(18 / 289)$ were published in books. A total of 39 of the selected studies were retrieved from the Journal of Medical Internet Research. Table 1 presents publication sources that published two or more selected studies.

It is worth noting that there might be relevant studies conducted in e-mental health and mobile health companies intended for internal use only and not published in scientific venues. The findings of such studies might offer new interesting insights and might help evolve the $\mathrm{CMH}$ field. 
Table 1. Publication sources that published more than one selected publication.

\begin{tabular}{|c|c|c|}
\hline Publication sources & Publications, $\mathrm{n}$ & References \\
\hline Journal of Medical Internet Research & 39 & [38-76] \\
\hline e-Mental Health & 8 & [77-84] \\
\hline Journal of Mental Health & 7 & {$[18,25,85-89]$} \\
\hline BMC Psychiatry & 7 & [90-96] \\
\hline Psychiatric Services & 7 & {$[22,97-102]$} \\
\hline Frontiers in Psychiatry & 7 & [103-109] \\
\hline Studies in Health Technology and Informatics & 6 & [110-115] \\
\hline Current Treatment Options in Psychiatry & 6 & [116-121] \\
\hline Journal of Technology in Human Services & 5 & {$[122-126]$} \\
\hline Professional Psychology: Research and Practice & 4 & [127-130] \\
\hline Australian and New Zealand Journal of Psychiatry & 4 & [131-134] \\
\hline Internet Interventions & 3 & [135-137] \\
\hline Current Psychiatry Reports & 3 & [138-140] \\
\hline Asian Journal of Psychiatry & 3 & [141-143] \\
\hline Australian Family Physician & 3 & [144-146] \\
\hline Evidence-Based Mental Health & 3 & [147-149] \\
\hline $\begin{array}{l}\text { Lecture Notes in Computer Science (including subseries Lecture Notes in Artificial } \\
\text { Intelligence and Lecture Notes in Bioinformatics) }\end{array}$ & 3 & {$[150-152]$} \\
\hline PLoS ONE & 3 & [153-155] \\
\hline International Journal of Mental Health Nursing & 3 & [156-158] \\
\hline Telemedicine and e-Health & 3 & [159-161] \\
\hline Psychiatric Times & 3 & [162-164] \\
\hline Frontiers in Public Health & 3 & [165-167] \\
\hline Health Informatics Journal & 3 & [168-170] \\
\hline Indian Journal of Psychological Medicine & 3 & [171-173] \\
\hline JAMA Psychiatry & 2 & {$[174,175]$} \\
\hline Journal of Psychosocial Nursing and Mental Health Services & 2 & {$[176,177]$} \\
\hline Journal of Physics: Conference Series & 2 & {$[178,179]$} \\
\hline BMC Medical Informatics and Decision Making & 2 & {$[180,181]$} \\
\hline Psychiatry (New York) & 2 & {$[182,183]$} \\
\hline Conference on Human Factors in Computing Systems_-Proceedings & 2 & {$[184,185]$} \\
\hline Journal of Affective Disorders & 2 & {$[186,187]$} \\
\hline Cyberpsychology, Behavior, and Social Networking & 2 & {$[188,189]$} \\
\hline Journal of Psychiatric Research & 2 & {$[190,191]$} \\
\hline European Journal of Psychotraumatology & 2 & {$[192,193]$} \\
\hline IEEE International Symposium on Computer-Based Medical Systems-Proceedings & 2 & {$[194,195]$} \\
\hline Advances in Mental Health & 2 & {$[196,197]$} \\
\hline The Digitization of Healthcare: New Challenges and Opportunities & 2 & {$[198,199]$} \\
\hline Australian Psychologist & 2 & {$[200,201]$} \\
\hline
\end{tabular}




\section{MQ3: What Are the Research Types of Studies Addressing CMH?}

Figure 3 presents the research types identified in the selected papers. The largest number of the selected publications were exploratory research $(104 / 289,35.9 \%)$, followed by reviews $(61 / 289,21.1 \%)$ and solution proposals $(49 / 289,16.9 \%)$; however, $10.0 \%$ (29/289) and only $1.3 \%$ (4/289) were evaluation studies and validation research, respectively.

Figure 3. Bubble graph associating the research types with the empirical types and the contribution types.
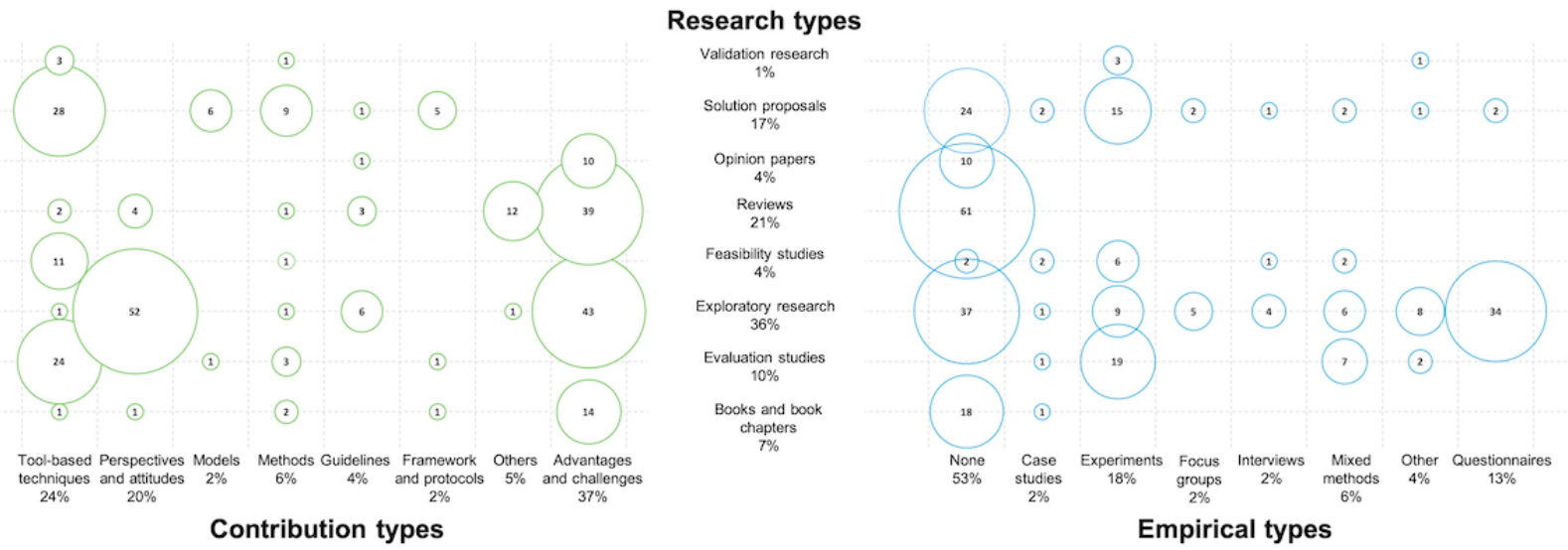

\section{MQ4: What Are the Contributions of the Selected CMH Studies?}

Figure 3 shows the different contributions of the selected papers: $36.6 \%(106 / 289)$ of the selected studies addressed the advantages, challenges, and limitations of $\mathrm{CMH} ; 24.2 \%$ (70/289) proposed tool-based solutions; and 19.7\% (57/289) investigated perspectives and attitudes toward CMH. Only 3.8\% (11/289) of the studies presented guidelines, and only $2.4 \%(7 / 289)$ provided frameworks and protocols.

\section{MQ5: What Are the Empirical Types of the Selected CMH Studies?}

Figure 3 shows the identified empirical types of the selected papers. Overall, $52.5 \%(152 / 289)$ of the studies were not evaluated empirically, and $17.9 \%$ (52/289) and 12.4\% (36/289) were evaluated empirically through experiments and questionnaires, respectively. Only a few publications used empirical evaluation methods such as case studies (7/289, 2.4\%), focus groups $(7 / 289,2.4 \%)$, and interviews $(6 / 289,2.0 \%)$. In addition, $10.0 \%(29 / 289)$ of the studies implemented either a mixed method approach $(17 / 289,5.8 \%)$ or used a different, not largely used empirical evaluation approach (12/289, 4.1\%).

\section{MQ6: What Are the Mental Health Issues Addressed in the CMH Literature?}

Figure 4 shows the mental health issues identified in the selected studies. Most of the selected studies (219 publications) addressed mental well-being in general. A total of 38 publications addressed depression, whereas 22 publications focused on anxiety. Furthermore, 37 papers addressed serious mental illnesses such as bipolar disorder, psychosis, schizophrenia, personality disorders, dementia, panic disorders, and major depressive disorders. Among the identified mental health issues addressed in the selected papers were addiction, suicide, cognitive disorders, sleeping disorders, emotional problems, mindfulness, and productivity influenced by mental state.

Figure 4. Mental health issue types versus targeted cohort. The color and the percentage represent the frequency of appearance of a problem in the selected studies dealing with a specific cohort.

\begin{tabular}{|c|c|c|c|c|c|c|c|c|c|c|c|c|c|}
\hline Problems & $\begin{array}{l}\text { No specific } \\
\text { group }(\mathrm{N}=200)\end{array}$ & $\begin{array}{l}\text { Young } \\
\text { people } \\
(\mathrm{N}=33)\end{array}$ & $\begin{array}{l}\text { Adolescent } \\
(\mathrm{N}=12)\end{array}$ & $\begin{array}{l}\text { Children } \\
(\mathrm{N}=9)\end{array}$ & $\begin{array}{l}\text { Clinicians } \\
(\mathrm{N}=14)\end{array}$ & $\begin{array}{l}\text { Workforce } \\
(\mathrm{N}=8)\end{array}$ & $\begin{array}{l}\text { Veterans and } \\
\text { partners }(N=7)\end{array}$ & $\begin{array}{l}\text { Adults } \\
(\mathrm{N}=4)\end{array}$ & $\begin{array}{l}\text { Women } \\
(\mathrm{N}=4)\end{array}$ & $\begin{array}{l}\text { Elderly } \\
(\mathrm{N}=3)\end{array}$ & \begin{tabular}{|l} 
Parents \\
$(\mathrm{N}=2)$
\end{tabular} & $\begin{array}{l}\text { Refugees } \\
(\mathrm{N}=1)\end{array}$ & \begin{tabular}{|l} 
Cancer \\
patients \\
$(\mathrm{N}=1)$
\end{tabular} \\
\hline $\begin{array}{l}\text { General mental health } \\
(\mathrm{N}=219)\end{array}$ & $74.5 \%$ & $69.7 \%$ & $75.0 \%$ & $88.9 \%$ & $78.6 \%$ & $75.0 \%$ & $57.1 \%$ & $75.0 \%$ & $25.0 \%$ & $100.0 \%$ & $50.0 \%$ & $100.0 \%$ & $0.0 \%$ \\
\hline Depression ( $N=38)$ & $11.5 \%$ & $15.2 \%$ & $25.0 \%$ & $11.1 \%$ & $7.1 \%$ & $12.5 \%$ & $0.0 \%$ & $25.0 \%$ & $50.0 \%$ & $0.0 \%$ & $0.0 \%$ & $0.0 \%$ & $100.0 \%$ \\
\hline Serious mental illness $(\mathrm{N}=37$ ) & $15.0 \%$ & $0.0 \%$ & $25.0 \%$ & $33.3 \%$ & $7.1 \%$ & $0.0 \%$ & $0.0 \%$ & $0.0 \%$ & $0.0 \%$ & $0.0 \%$ & $0.0 \%$ & $0.0 \%$ & $0.0 \%$ \\
\hline Anxiety $(\mathrm{N}=22)$ & $7.0 \%$ & $12.1 \%$ & $8.3 \%$ & $11.1 \%$ & $7.1 \%$ & $0.0 \%$ & $0.0 \%$ & $25.0 \%$ & $0.0 \%$ & $0.0 \%$ & $0.0 \%$ & $0.0 \%$ & $0.0 \%$ \\
\hline $\begin{array}{l}\text { Behavioral and emotional } \\
\text { problems }(\mathrm{N}=15)\end{array}$ & $2.5 \%$ & $9.1 \%$ & $25.0 \%$ & $11.1 \%$ & $7.1 \%$ & $0.0 \%$ & $14.3 \%$ & $0.0 \%$ & $0.0 \%$ & $0.0 \%$ & $50.0 \%$ & $0.0 \%$ & $0.0 \%$ \\
\hline Stress $(N=13)$ & $3.5 \%$ & $9.1 \%$ & $0.0 \%$ & $0.0 \%$ & $7.1 \%$ & $12.5 \%$ & $0.0 \%$ & $0.0 \%$ & $25.0 \%$ & $0.0 \%$ & $0.0 \%$ & $0.0 \%$ & $0.0 \%$ \\
\hline $\begin{array}{l}\text { Post-traumatic stress } \\
\text { disorder }(\mathrm{N}=7)\end{array}$ & $1.5 \%$ & $0.0 \%$ & $0.0 \%$ & $0.0 \%$ & $0.0 \%$ & $12.5 \%$ & $42.9 \%$ & $0.0 \%$ & $0.0 \%$ & $0.0 \%$ & $0.0 \%$ & $0.0 \%$ & $0.0 \%$ \\
\hline Sleeping disorders $(\mathrm{N}=5)$ & $1.0 \%$ & $3.0 \%$ & $8.3 \%$ & $11.1 \%$ & $0.0 \%$ & $0.0 \%$ & $0.0 \%$ & $0.0 \%$ & $0.0 \%$ & $0.0 \%$ & $0.0 \%$ & $0.0 \%$ & $0.0 \%$ \\
\hline $\begin{array}{l}\text { Body image issues and } \\
\text { eating disorders }(\mathrm{N}=5)\end{array}$ & $0.5 \%$ & $0.0 \%$ & $16.7 \%$ & $22.2 \%$ & $0.0 \%$ & $0.0 \%$ & $0.0 \%$ & $0.0 \%$ & $0.0 \%$ & $0.0 \%$ & $0.0 \%$ & $0.0 \%$ & $0.0 \%$ \\
\hline Addiction (N-4) & $1.5 \%$ & $3.0 \%$ & $0.0 \%$ & $0.0 \%$ & $0.0 \%$ & $0.0 \%$ & $0.0 \%$ & $0.0 \%$ & $0.0 \%$ & $0.0 \%$ & $0.0 \%$ & $0.0 \%$ & $0.0 \%$ \\
\hline Suicide and self-harm $(\mathrm{N}=4)$ & $1.0 \%$ & $0.0 \%$ & $8.3 \%$ & $11.1 \%$ & $0.0 \%$ & $0.0 \%$ & $0.0 \%$ & $0.0 \%$ & $0.0 \%$ & $0.0 \%$ & $0.0 \%$ & $0.0 \%$ & $0.0 \%$ \\
\hline Cognitive disorders $(\mathrm{N}=4)$ & $1.0 \%$ & $3.0 \%$ & $0.0 \%$ & $0.0 \%$ & $0.0 \%$ & $0.0 \%$ & $0.0 \%$ & $0.0 \%$ & $0.0 \%$ & $33.3 \%$ & $0.0 \%$ & $0.0 \%$ & $0.0 \%$ \\
\hline
\end{tabular}




\section{MQ7: Who Are the Targeted Cohorts in the Selected CMH Studies?}

Figure 4 shows all groups identified in the studies. Most studies (200 selected publications) did not address a particular group of people. The remaining publications focused either on age-based groups, such as children, adolescents, and the elderly, or on specific groups, such as veterans, refugees, and cancer patients.

\section{MQ8: In Which Countries Were the Selected Empirically Evaluated Studies Conducted?}

Figure 5 shows the geographical distribution of the selected empirically evaluated studies. Most studies were conducted in Australia, followed by the United States and Canada. Some studies included more than one country and were counted for each one.

Figure 5. Geographical distribution of empirically evaluated studies. E-mental: electronic mental; tele-mental health: telehealth for mental health.

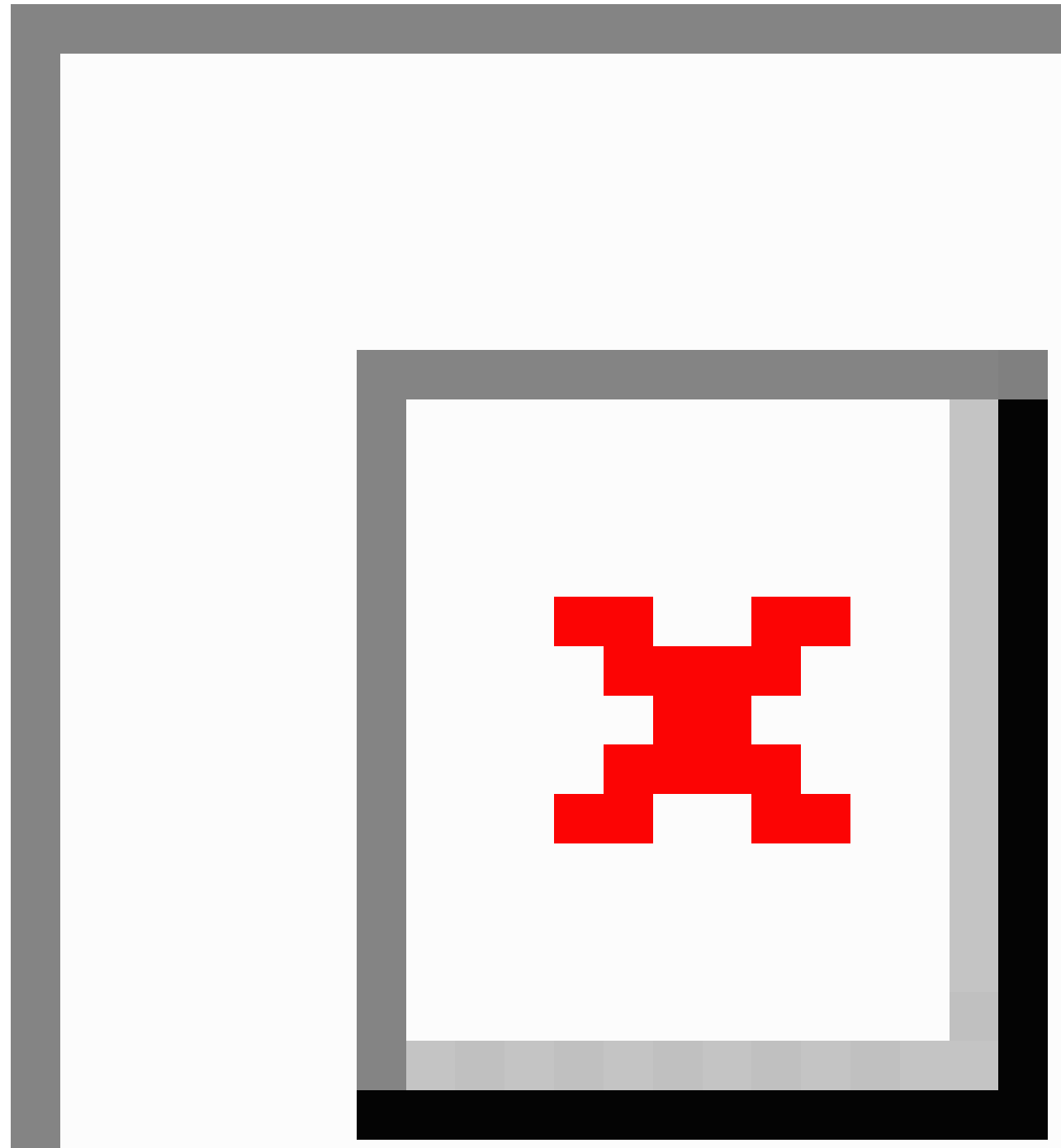




\section{Discussion}

\section{Principal Findings}

\section{Trends in Publication and Usage of Terms}

There has been an increasing interest in $\mathrm{CMH}$ publications in the past decade. This can be explained by the fact that $\mathrm{CMH}$ research has been influenced continuously by novel technological interventions and the growth in ICT usage, especially with the appearance of Web 2.0 between 2003 and 2004 [202]. Web 2.0 introduced an architecture of participation [203], focusing on social interactions and collective intelligence [204]. These changes were accompanied by a significant increase in the number of internet users worldwide [205] as well as ownership and usage of smartphones [206] and computers [207-209]. This has also impacted the use of ICT, which has been incorporated in many fields, including transport [210], tourism [211], education [212], virtual work teams [213], and health care [214].

An increase in the number of publications in the field of $\mathrm{CMH}$ could have also been influenced by the changes in the general literature. There has been a shift from paper copies to electronic copies, which significantly increased the accessibility to published studies, particularly open access publications [215]. Consequently, the research evaluations performed by peers became reliant on different bibliometrics [216]. The productivity of researchers has mainly been measured by bibliometrics (eg, journal's impact factor [217,218] and researcher's h-index [219]), which is impacting hiring processes, academic promotion, and funding decisions [219,220]. This puts more pressure on researchers to produce more publications in the literature, particularly publications indexed in Scopus.

The earliest term used in the selected $\mathrm{CMH}$ studies was telemental health, which falls in the same group of terms as telemedicine and telepsychiatry. These terms have been used to describe remote health care and informatization of some elements of the health care process since the 1990s [221,222]. The term telemental health has rarely been used in recent years as $e$-mental health began emerging since 2006.

The term eHealth was introduced in the late 1990s. It was defined at the 7th International Congress on Telemedicine and Telecare in London at the end of November 1999 by John Mitchell as "a new term needed to describe the combined use of electronic communication and information technology in the health sector" and as "the health industry's equivalent of e-commerce" [223]. Although previously used terms were linked to medical professionals, eHealth was found to be driven by nonprofessionals, namely, patients (or consumers) [224]. Many journals after the introduction of eHealth changed their names to include it; for example, the Telemedicine Journal added an "and eHealth" to its title. Nevertheless, publications were not including the term eHealth, and researchers preferred to use more specific terms such as medical informatics, telemedicine, and electronic patient records, which are considered more meaningful than the generic term eHealth [223]. This might explain its late and delayed emergence in the literature.
The trend of publications also showed an increasing use of the term m-mental health, primarily since 2010 . The expansion in the use and ownership of smartphones [225] brings new opportunities for the mental health care industry to face some of the most pressing global challenges and make mental health care more accessible, faster, less expensive, and better [226]. Studies have proven the interest and willingness of people with mental health issues to try mobile solutions [73,227]. Hence, it is expected that m-mental health will continue to attract the attention of $\mathrm{CMH}$ researchers and practitioners.

The term digital mental health has been used since 2011. This term is associated with the use of recent and advanced technologies, such as sensors [228] and machine learning techniques, and it has been used as a modern synonym for e-mental health, especially since 2017 . It must be noted that researchers use different terms to refer to the same concept, and, in many studies, authors use more than one term, which might occasionally create confusion, especially in cases in which known definitions of each term overlap. Consequently, there is a need for a broad term such as connected mental health to encompass the different terms used. Although connected health has become an established field [20], we did not find the use of such a term in mental health care. To the best of our knowledge, this is the first study that uses this term to refer to the use of ICT in mental health.

\section{Publication Channels}

Most of the selected papers $(238 / 289,82.3 \%)$ were published in scientific journals. Publishing in a rigorous scientific journal is based on a set of ethics and rules [229] that can result in the production of high-quality content. This result could have been impacted also by the choice of digital library. More journals than conference proceedings in $\mathrm{CMH}$ might have satisfied the criteria of Scopus indexation. There are also many scientific journals that are categorized in health informatics. This encourages researchers to conduct studies suited for journals and indicates a particular level of maturity in the field from a quantitative perspective. Articles published in journals tend to be more detailed and extensive. Conferences are also an important venue for publications. Conferences with proceedings provide fast tracking of publication to keep researchers and practitioners up to date with the latest findings. The first identified publication in the selected studies, which appeared in 2003, was a book. Books are used to introduce or provide a detailed overview of a topic.

\section{Research Types and Empirical Types}

The multidisciplinary nature of the $\mathrm{CMH}$ field and its various subareas resulted in a high ratio of exploratory research and reviews compared with other types of research, such as solution proposals, validation, and evaluation research. The diversity of the identified empirical evaluation types points to the uncertainty regarding adequate methods to evaluate $\mathrm{CMH}$ solutions. There is a need for evidence-based studies that will verify the efficiency of $\mathrm{CMH}$ interventions, create accurate results for future research, and identify challenges that need to be addressed. Most of the selected studies (152/289, 52.5\%) were not evaluated empirically, which can be linked to the fact that a large number of empirical evaluation studies in the health 
informatics field have not been published [230]. Most of the remaining studies were empirically evaluated through experiments $(52 / 289,17.9 \%)$, primarily owing to their controlled environments. Case studies are more suited for sensitive problems such as mental health issues and would be more beneficial for the growth of the field, as they help identify many issues that can be faced in real-life implementation of ICT interventions. However, only $2.4 \%$ (7/289) of the selected studies were evaluated empirically through case studies. Questionnaires represented an important part of the empirical evaluation methods of the selected studies $(36 / 289,12.4 \%)$ used mainly in exploratory research $(104 / 289,35.9 \%)$ to investigate perspectives and attitudes toward the use of technology for mental health and on advantages, challenges, and limitations of CMH. Questionnaires are useful tools for data collection as they can be formulated to collect significant amounts and various types of data and can be delivered through various means to reach large groups of people.

\section{Contributions of the Selected Studies}

The largest number of the selected studies focused on investigating the advantages, benefits, risks, challenges, and limitations of CMH $(106 / 289,36.6 \%)$ as well as perspectives and attitudes of patients, clinicians, and various stakeholders toward CMH (57/289, 19.7\%). An important part of the identified contributions was about tool-based techniques $(70 / 289,24.2 \%)$, whereas only a few studies represented frameworks, protocols, and models $(14 / 289,4.8 \%)$. This points to a level of ambiguity in the field as frameworks, protocols, and models are typically signs of clear understanding of a concept, its benefits, and its limitations. Tool-based techniques are usually relatively specific to one area of implementation and target a specific need, for instance, a mobile app for tracking mood changes or a website for evaluating levels of depression. Despite an increasing number of $\mathrm{CMH}$ publications, the types of research identified are primarily theoretical and hypothetical, indicating that researchers are still proposing their conceptual ideas for CMH. Only 4.4\% (13/289) of the studies, categorized as others in Figure 3, addressed topics such as effectiveness, efficiency, usability, and quality of technological solutions for mental health care. The lack of publications on these topics is related to the aforementioned lack of empirical evaluation studies.

\section{Mental Disorders and the Targeted Cohort}

Most of the selected studies did not target a specific group of people $(200 / 289,69.2 \%)$. The remaining studies focused primarily on young people, adolescents, and children (33/89, $37 \% ; 12 / 89,13 \%$; and $9 / 89,10 \%$, respectively). There was an overlap of age ranges among the categories, primarily owing to the existing overlapping of ages in the known definitions of the categories. The World Health Organization defines adolescence as the age range spanning from 10 to 19 years, youth as those aged between 15 and 24 years, and young people as the group covering the 2 categories from 10 to 24 years [231]. The adolescent group is further divided to include a subgroup of early adolescence (11-14 years) [232], which might be referred to by some authors as children. Targeting primarily the young category of patients can be explained by the fact that this category is characterized by the ownership of mobile devices, high usage of the internet and social networks, and familiarity with the use of technology, which makes it easy for them to become customers of CMH solutions.

On the basis of our findings, the young people category is the main target for studies on technological solutions for depression, anxiety, and related issues. These disorders are the third leading cause of death among adolescents and young adults, with a prevalence of approximately $4 \%$ in children and $10 \%$ to $20 \%$ in adolescents [233]. Other mental health issues such as body image issues, eating disorders, and sleep problems are also common among young people. Most mental health issues identified in this category could be linked to young people's extensive use of social networks and living a digital life, making them disconnected from real life and absorbed in following other people's lives and comparing them with their own lives. In many cases, this can cause them to feel worthless and disappointed with their lives, bodies, or achievements. Internet use has become an addiction for many young people, causing, among other problems, loss of sleep and high levels of loneliness [234] as well as many cyber-related mental problems [235].

Depression, followed by anxiety, was identified among most of the cohort groups, owing primarily to the increasing global expression of these disorders. The global population with depression increased by $18.4 \%$ between 2005 and 2015; similarly, the total number of people with anxiety increased by $14.9 \%$ between 2005 and 2015 [236]. Depression can occur as a result of other health problems, such as perinatal and postpartum depression among women [155,237] and common depression among cancer patients [238].

Many serious disorders such as schizophrenia, psychosis, and personality disorders were the subjects of many of the selected studies, pointing to the potential of using $\mathrm{CMH}$ not only for common mental disorders but also for more severe and complicated mental problems.

Most of the selected CMH publications addressed general mental well-being. Having more studies focusing on specific mental issues might help identify specific limitations and issues as well as highlight opportunities related to specific disorders. More studies should also focus on people in war zones as they are vulnerable to various mental problems and have more barriers to obtain mental health care, which CMH can help solve [239].

\section{Countries in Which the Empirical Evaluations Were Conducted}

Most empirical evaluations were conducted in developed English-speaking countries such as Australia, the United States, Canada, and England. This might be mainly owing to the advancement in research in these countries. In Australia, universities are considered world-leading in at least one area of research [240], and large investments are provided to research institutes [241]. There is an important research interest in health informatics in Australia [242]. Research in the United States is believed to be essential to the country's economic growth. Therefore, the federal government has devoted a significant amount of funding for research [243]. The United States has many of the most accomplished individuals in the field of health 
informatics working in research projects and institutions specialized in the field [244]. Several developing countries have good ICT infrastructures and can benefit from different $\mathrm{CMH}$ interventions to solve several existing issues; however, limited research is conducted in developing countries. The same goes for war zones as only 2 studies addressed people in war zones: one conducted for Palestinian children [245] and the other addressed Syrian refugees in Germany, Sweden, and Egypt [106]. CMH interventions are solutions to overcome mental care barriers in developing countries and war zones. Research in this field should be shifted to countries that are most in need of CMH solutions.

\section{Comparison With Related Studies}

The findings of this study are aligned with the findings of other studies related to $\mathrm{CMH}$ :

- The identified increase in interest in the $\mathrm{CMH}$ literature was also reported in a literature review of e-mental health [133].

- The identified lack of empirical evaluation of the proposed solutions was reflected in the findings of a meta-analysis on digital interventions for alcohol and substance use disorders, reporting limitations in the number of randomized control trials (RCTs) in that area [117]. Another review on RCTs on the effectiveness of occupational e-mental health concluded the need for more detailed and specific effectiveness research [246]. A narrative review on digital mental health in developing countries reported a shortage of studies on the effectiveness and cost-effectiveness of the investigated internet-based programs [166]. A review on the effectiveness of mobile apps reported a lack of clinically validated evidence on the efficiency of most available apps [191].

- There was a lack of use of the term telemental health. Related findings were described in a review of the directions for videoconferencing and telemental health [247]. The review reported a limited number of RCTs in the field as well as methodologically flawed and limited research studies, which resulted in the research agenda of telemental health not being fully maximized [247].

- Leading countries in the empirical studies selected were Australia and the United States, which are similar to findings from other reviews. A review reported that evidence for telemental health and web-based solutions are largely led by Australia [138]. Two reviews reported that most of their selected publications were found to have mostly originated in the United States and Australia [22,133], and a study [133] found that Australian e-mental health research was higher in diversity and quantity.

\section{Limitations}

This study has some limitations. This study did not include other digital databases. However, Scopus is widely considered to be the largest indexing digital library that includes publications from different disciplines [35]. This allowed us to identify different contributions in $\mathrm{CMH}$ research. It should be noted that Web of Science (WoS) was not considered as a recent study showed that slight differences exist between the scientific literature covered in Scopus and WoS Core Collection, which will result in a large number of duplicates [248].

The search strings were applied only to the titles to limit the sizes of the selection and to include only relevant and focused CMH publications, possibly omitting other candidate studies. However, we considered that if a paper's principal focus was $\mathrm{CMH}$, then at least one of the terms from the search strings could be expected to appear in the title, alleviating the risk of discarding relevant publications for this mapping study.

Other terms, particularly terms related to different mental health issues, might have been relevant for inclusion in the search strings, possibly impacting the results. However, our aim was to provide a high-level overview of existing $\mathrm{CMH}$ literature.

Other classification criteria might have been relevant to extracting further information from the selected studies, possibly affecting our findings. However, the principal aim of this systematic mapping study was to provide an overview of $\mathrm{CMH}$ literature, and the process and criteria presented in the Methods section fit this purpose.

The final study selection depended on the first two authors, ND and SO, who conducted the search process. The first author conducted a preliminary search in Scopus and constructed a preliminary selection of publications. The second author revised the selection. If a disagreement arose between the two authors on the exclusion or inclusion of a paper, then a discussion took place until an agreement was reached. It should be noted that the two authors have experience in conducting mapping studies and systematic literature reviews [228,249,250].

\section{Conclusions}

This paper conducted a systematic mapping study of 289 publications indexed in Scopus and provided an overview of the available literature on $\mathrm{CMH}$ research. $\mathrm{CMH}$ has the potential to overcome some of the mental health care delivery barriers by introducing and exploiting ICT in the process of mental health care. A total of 289 publications were selected, analyzed, and classified. The results showed that $\mathrm{CMH}$ is a promising research field that has gained increasing attention from researchers over the years. The frequency of the selected publications was influenced by the continuous developments in digital media and the use of ICT as well as the changes in literature evaluation methods, which mainly relied on bibliometrics. The results also showed that most of the selected $\mathrm{CMH}$ literature addressed general mental well-being; depression and anxiety were the mental disorders most addressed in studies on specific mental issues, which is in accordance with their global prevalence; young people were the most targeted cohort group as they are more familiar with digital solutions; exploratory research and reviews were the dominant research types found in the selected literature, which indicates that researchers are more focused on exploring possible venues of implementation of ICT in mental health care and constructing an understanding of the field; and most of the selected studies were not empirically evaluated. Moreover, the results showed that selected studies that were empirically evaluated were mostly conducted in developed countries. Screening of the selected studies that were reviews showed that they targeted specific 
cohort groups, specific mental disorders, specific types of solutions, or specific terms. To the best of our knowledge, this is the first mapping study that addresses the field of $\mathrm{CMH}$ as a whole, including all relevant terms and without excluding any specific criteria. On the basis of our findings, we recommend the following to researchers:

- Shift attention to provide evidence-based solutions and studies, and empirically evaluate existing solutions in future CMH studies.

- Focus on specific mental issues and cohort groups to better identify possible issues and limitations of the field.

- Investigate CMH solution implementation in developing countries and war zones, which experience various mental care delivery barriers.
- Use connected mental health as an englobing term for the exploitation of the different types of ICT in mental health care.

Practitioners can use this study to find tool-based studies for specific cohorts and/or mental disorders. They can also find studies related to the attitudes and behaviors of $\mathrm{CMH}$ users.

We believe that our study will provide researchers and practitioners with relevant information regarding the existing $\mathrm{CMH}$ literature as well as recommendations for future publications. For future work, we intend to develop a conceptual framework for sustainable $\mathrm{CMH}$ solutions.

\section{Acknowledgments}

This work is part of the Startup project (number 31T131) funded by the United Arab Emirates University (2019-2021).

\section{Authors' Contributions}

All authors contributed to the creation of the manuscript. ND contributed to the design, conception, acquisition and interpretation of data, classification of selected papers, drafting of the manuscript, and revision. SO contributed to the design, conception, statistical support, interpretation of data, drafting of the manuscript, and critical revision. MJ, JL, and MG performed the critical revision. All authors have read and approved this manuscript.

\section{Conflicts of Interest}

LL is a shareholder of Salumedia Labs, which is a digital health company.

\section{Multimedia Appendix 1}

Classification results.

[XLSX File (Microsoft Excel File), 44 KB-Multimedia Appendix 1]

\section{References}

1. Westerhof GJ, Keyes CL. Mental illness and mental health: the two continua model across the lifespan. J Adult Dev 2010 Jun;17(2):110-119 [FREE Full text] [doi: 10.1007/s10804-009-9082-y] [Medline: 20502508]

2. Sawyer MG, Whaites L, Rey JM, Hazell PL, Graetz BW, Baghurst P. Health-related quality of life of children and adolescents with mental disorders. J Am Acad Child Adolesc Psychiatry 2002 May;41(5):530-537. [doi: 10.1097/00004583-200205000-00010] [Medline: 12014785]

3. Prince M, Patel V, Saxena S, Maj M, Maselko J, Phillips MR, et al. No health without mental health. Lancet 2007 Sep 8;370(9590):859-877. [doi: 10.1016/S0140-6736(07)61238-0] [Medline: 17804063]

4. Patel V, Flisher AJ, Hetrick S, McGorry P. Mental health of young people: a global public-health challenge. Lancet 2007 Apr 14;369(9569):1302-1313. [doi: 10.1016/S0140-6736(07)60368-7] [Medline: 17434406]

5. Layard R. Mental Illness Destroys Happiness and is Costless to Treat. Global Happiness. 2018. URL: http://ghc-2018. s3.amazonaws.com/GHC Ch3.pdf [accessed 2020-04-30]

6. Sachs SJ, Layard R, Helliwell J. World Happiness Report 2018. AWS. 2018. URL: https://s3.amazonaws.com/ happiness-report/2018/WHR web.pdf [accessed 2020-04-30]

7. Collins PY, Patel V, Joestl SS, March D, Insel TR, Daar AS, et al. Grand challenges in global mental health. Nature 2011 Jul 6;475(7354):27-30 [FREE Full text] [doi: 10.1038/475027a] [Medline: 21734685]

8. Patel V, Prince M. Global mental health: a new global health field comes of age. J Am Med Assoc 2010 May 19;303(19):1976-1977 [FREE Full text] [doi: 10.1001/jama.2010.616] [Medline: 20483977]

9. Rowan K, McAlpine DD, Blewett LA. Access and cost barriers to mental health care, by insurance status, $1999-2010$. Health Aff (Millwood) 2013 Oct;32(10):1723-1730 [FREE Full text] [doi: 10.1377/hlthaff.2013.0133] [Medline: 24101061]

10. Cunningham PJ. Beyond parity: primary care physicians' perspectives on access to mental health care. Health Aff (Millwood) 2009;28(3):w490-w501. [doi: 10.1377/hlthaff.28.3.w490] [Medline: 19366722]

11. Gulliver A, Griffiths KM, Christensen H. Perceived barriers and facilitators to mental health help-seeking in young people: a systematic review. BMC Psychiatry 2010 Dec 30;10:113 [FREE Full text] [doi: 10.1186/1471-244X-10-113] [Medline: $\underline{21192795]}$ 
12. Snowden LR. Barriers to effective mental health services for African Americans. Ment Health Serv Res 2001 Dec;3(4):181-187. [doi: 10.1023/a:1013172913880] [Medline: 11859964]

13. Coronavirus. World Health Organization. URL: https://www.who.int/health-topics/coronavirus\#tab=tab 1 [accessed 2020-04-30]

14. Coronavirus Disease (COVID-19) Weekly Epidemiological Update and Weekly Operational Update. World Health Organization. 2020. URL: https://www.who.int/emergencies/diseases/novel-coronavirus-2019/situation-reports [accessed 2020-04-30]

15. Anxiety on Rise Due to Coronavirus, Say Mental Health Charities. The Guardian. URL: https://www.theguardian.com/ world/2020/mar/13/anxiety-on-rise-due-to-coronavirus-say-mental-health-charities [accessed 2020-04-30]

16. Mental Health and Psychosocial Considerations During the Covid-19 Outbreak. World Health Organization. URL: https:/ /www.who.int/docs/default-source/coronaviruse/mental-health-considerations.pdf?sfvrsn=6d3578af 2 [accessed 2020-04-30]

17. Coronavirus Disease (COVID-19) Advice for the Public. World Health Organization. 2020. URL: https://www.who.int/ emergencies/diseases/novel-coronavirus-2019/advice-for-public [accessed 2020-04-30]

18. Schmidt U, Wykes T. E-mental health - a land of unlimited possibilities. J Ment Health 2012 Aug;21(4):327-331. [doi: 10.3109/09638237.2012.705930] [Medline: 22823092]

19. Caulfield BM, Donnelly SC. What is Connected Health and why will it change your practice? QJM 2013 Aug;106(8):703-707. [doi: 10.1093/qjmed/hct114] [Medline: 23676416]

20. Karampela M, Isomursu M, Porat T, Maramis C, Mountford N, Giunti G, et al. The extent and coverage of current knowledge of connected health: systematic mapping study. J Med Internet Res 2019 Sep 25;21(9):e14394 [FREE Full text] [doi: 10.2196/14394] [Medline: 31573915 ]

21. Nicholas J, Huckvale K, Larsen ME, Basu A, Batterham PJ, Shaw F, et al. Issues for ehealth in psychiatry: results of an expert survey. J Med Internet Res 2017 Feb 28;19(2):e55 [FREE Full text] [doi: 10.2196/jmir.6957] [Medline: 28246068]

22. Lal S, Adair CE. E-mental health: a rapid review of the literature. Psychiatr Serv 2014 Jan 1;65(1):24-32. [doi: 10.1176/appi.ps.201300009] [Medline: 24081188]

23. Helen C, Griffiths K, Evans K. e-Mental health in Australia: Implications of the Internet and related technologies for policy. Canberra: Commonwealth Department of Health and Ageing; 2002.

24. Sood S, Mbarika V, Jugoo S, Dookhy R, Doarn CR, Prakash N, et al. What is telemedicine? A collection of 104 peer-reviewed perspectives and theoretical underpinnings. Telemed J E Health 2007 Oct;13(5):573-590. [doi: 10.1089/tmj.2006.0073] [Medline: 17999619]

25. Bauer S, Moessner M. Technology-enhanced monitoring in psychotherapy and e-mental health. J Ment Health 2012 Aug;21(4):355-363. [doi: 10.3109/09638237.2012.667886] [Medline: 22548363]

26. Wade VA, Karnon J, Elshaug AG, Hiller JE. A systematic review of economic analyses of telehealth services using real time video communication. BMC Health Serv Res 2010 Aug 10;10:233 [FREE Full text] [doi: 10.1186/1472-6963-10-233] [Medline: 20696073]

27. Mitrpanont J, Phandhu-Fung J, Klubdee N, Ratanalaor S, Mitrpanont T. iCare-Stress: An Integrated Mental Health Software. In: 2nd International Conference on Information Technology. 2017 Presented at: INCIT'17; November 2-3, 2017; Nakhonpathom, Thailand. [doi: 10.1109/incit.2017.8257889]

28. Owen JE, Kuhn E, Jaworski BK, McGee-Vincent P, Juhasz K, Hoffman JE, et al. VA mobile apps for PTSD and related problems: public health resources for veterans and those who care for them. Mhealth 2018;4:28 [FREE Full text] [doi: 10.21037/mhealth.2018.05.07] [Medline: 30148141]

29. Batterham PJ, Calear AL, Farrer L, McCallum SM, Cheng VW. Randomised controlled trial of an automatically tailored online program for mood, anxiety, substance use and suicidality. Internet Interv 2018 Jun;12:91-99 [FREE Full text] [doi: 10.1016/j.invent.2017.08.002] [Medline: 30135773 ]

30. Jani HM. Benefiting From Online Mental Status Examination System and Mental Health Diagnostic System. In: 3rd International Conference on Information Sciences and Interaction Sciences. 2010 Presented at: ICICIS'10; June 23-25, 2010; Chengdu, China. [doi: 10.1109/icicis.2010.5534712]

31. Sahu SS, Sharma A. Detecting Brainwaves to Evaluate Mental Health Using Labview and Applications. In: International Conference on Emerging Technological Trends. 2016 Presented at: ICETT'16; October 21-22, 2016; Kollam, India. [doi: 10.1109/icett.2016.7873738]

32. Pham TD, Thang T, Oyama-Higa M. Toward the Development of a Cost-effective E-depression Detection System. In: International Conference on Computerized Healthcare. 2012 Presented at: ICCH'12; December 17-18, 2012; Hong Kong, China. [doi: 10.1109/icch.2012.6724465]

33. Peterson K, Feldt R, Mujtaba S, Mattsson M. Systematic Mapping Studies in Software Engineering. In: 12th International Conference on Evaluation and Assessment in Software Engineering. 2008 Presented at: EASE'08; June 26-27, 2008; Bari, Italy. [doi: 10.14236/ewic/ease2008.8]

34. Petersen K, Vakkalanka S, Kuzniarz L. Guidelines for conducting systematic mapping studies in software engineering: an update. Inform Software Tech 2015 Aug;64:1-18. [doi: 10.1016/j.infsof.2015.03.007]

35. Montoya FG, Alcayde A, Baños R, Manzano-Agugliaro F. A fast method for identifying worldwide scientific collaborations using the Scopus database. Telematics and Informatics 2018 Apr;35(1):168-185. [doi: 10.1016/j.tele.2017.10.010] 
36. Hamel RE. The dominance of English in the international scientific periodical literature and the future of language use in science. Aila Rev 2008 Mar 7;20:53-71. [doi: 10.1075/aila.20.06ham]

37. Ammon U. The Dominance of English as a Language of Science: Effects on Other Languages and Language Communities. New York, USA: Walter de Gruyter; 2011.

38. Liverpool S, Webber H, Matthews R, Wolpert M, Edbrooke-Childs J. A mobile app to support parents making child mental health decisions: protocol for a feasibility cluster randomized controlled trial. JMIR Res Protoc 2019 Aug 14;8(8):e14571 [FREE Full text] [doi: 10.2196/14571] [Medline: 31414665]

39. Schueller SM, Glover AC, Rufa AK, Dowdle CL, Gross GD, Karnik NS, et al. A mobile phone-based intervention to improve mental health among homeless young adults: pilot feasibility trial. JMIR Mhealth Uhealth 2019 Jul 2;7(7):e12347 [FREE Full text] [doi: 10.2196/12347] [Medline: $\underline{\text { 31267980] }}$

40. Coelhoso CC, Tobo PR, Lacerda SS, Lima AH, Barrichello CR, Amaro E, et al. A new mental health mobile app for well-being and stress reduction in working women: randomized controlled trial. J Med Internet Res 2019 Nov 7;21(11):e14269 [FREE Full text] [doi: 10.2196/14269] [Medline: 31697244]

41. Garabiles MR, Harper Shehadeh M, Hall BJ. Cultural adaptation of a scalable world health organization e-mental health program for overseas Filipino workers. JMIR Form Res 2019 Mar 29;3(1):e11600 [FREE Full text] [doi: 10.2196/11600] [Medline: 30924784$]$

42. Greer B, Robotham D, Simblett S, Curtis H, Griffiths H, Wykes T. Digital exclusion among mental health service users: qualitative investigation. J Med Internet Res 2019 Jan 9;21(1):e11696 [FREE Full text] [doi: 10.2196/11696] [Medline: 30626564]

43. Lattie EG, Adkins EC, Winquist N, Stiles-Shields C, Wafford QE, Graham AK. Digital mental health interventions for depression, anxiety, and enhancement of psychological well-being among college students: systematic review. J Med Internet Res 2019 Jul 22;21(7):e12869 [FREE Full text] [doi: 10.2196/12869] [Medline: 31333198]

44. Smail-Crevier R, Powers G, Noel C, Wang J. Health-related internet usage and design feature preference for e-mental health programs among men and women. J Med Internet Res 2019 Mar 18;21(3):e11224 [FREE Full text] [doi: 10.2196/11224] [Medline: 30882361$]$

45. Birk MV, Mandryk RL. Improving the efficacy of cognitive training for digital mental health interventions through avatar customization: crowdsourced quasi-experimental study. J Med Internet Res 2019 Jan 8;21(1):e10133 [FREE Full text] [doi: 10.2196/10133] [Medline: 30622095]

46. Thomas K, Bendtsen M. Mental health promotion among university students using text messaging: protocol for a randomized controlled trial of a mobile phone-based intervention. JMIR Res Protoc 2019 Aug 15;8(8):e12396 [FREE Full text] [doi: 10.2196/12396] [Medline: 31418426 ]

47. Anastasiadou D, Folkvord F, Serrano-Troncoso E, Lupiañez-Villanueva F. Mobile health adoption in mental health: user experience of a mobile health app for patients with an eating disorder. JMIR Mhealth Uhealth 2019 May 31;7(6):e12920 [FREE Full text] [doi: 10.2196/12920] [Medline: 31199329]

48. Andrews JA, Brown L, Hawley M, Astell A. Older adults' perspectives on using digital technology to maintain good mental health: interactive group study. J Med Internet Res 2019 Feb 13;21(2):e11694 [FREE Full text] [doi: 10.2196/11694] [Medline: 30758292]

49. Mandryk RL, Birk MV. The potential of game-based digital biomarkers for modeling mental health. JMIR Ment Health 2019 Apr 23;6(4):e13485 [FREE Full text] [doi: 10.2196/13485] [Medline: $\underline{\text { 31012857] }}$

50. Scholten H, Granic I. Use of the principles of design thinking to address limitations of digital mental health interventions for youth: viewpoint. J Med Internet Res 2019 Jan 14;21(1):e11528 [FREE Full text] [doi: 10.2196/11528] [Medline: 31344671]

51. Thornton L, Kay-Lambkin F, Tebbutt B, Hanstock TL, Baker AL. A mobile phone-based healthy lifestyle monitoring tool for people with mental health problems (MyHealthPA): development and pilot testing. JMIR Cardio 2018 Oct 1;2(2):e10228 [FREE Full text] [doi: 10.2196/10228] [Medline: $\underline{\text { 31758772] }}$

52. Kaur A, Isaranuwatchai W, Jaffer A, Ferguson G, Abi-Jaoude A, Johnson A, et al. A web- and mobile-based map of mental health resources for postsecondary students (Thought Spot): protocol for an economic evaluation. JMIR Res Protoc 2018 Mar 29;7(3):e83 [FREE Full text] [doi: 10.2196/resprot.9478] [Medline: 29599106]

53. Zelmer J, van Hoof K, Notarianni M, van Mierlo T, Schellenberg M, Tannenbaum C. An assessment framework for e-mental health apps in Canada: results of a modified delphi process. JMIR Mhealth Uhealth 2018 Jul 9;6(7):e10016 [FREE Full text] [doi: 10.2196/10016] [Medline: 29986846]

54. March S, Day J, Ritchie G, Rowe A, Gough J, Hall T, et al. Attitudes toward e-mental health services in a community sample of adults: online survey. J Med Internet Res 2018 Feb 19;20(2):e59 [FREE Full text] [doi: 10.2196/jmir.9109] [Medline: 29459357]

55. Carolan S, de Visser RO. Employees' perspectives on the facilitators and barriers to engaging with digital mental health interventions in the workplace: qualitative study. JMIR Ment Health 2018 Jan 19;5(1):e8 [FREE Full text] [doi: 10.2196/mental.9146] [Medline: 29351900] 
56. Hatch A, Hoffman JE, Ross R, Docherty JP. Expert consensus survey on digital health tools for patients with serious mental illness: optimizing for user characteristics and user support. JMIR Ment Health 2018 Jun 12;5(2):e46 [FREE Full text] [doi: 10.2196/mental.9777] [Medline: 29895514]

57. Palmius N, Saunders KE, Carr O, Geddes JR, Goodwin GM, De Vos M. Group-personalized regression models for predicting mental health scores from objective mobile phone data streams: observational study. J Med Internet Res 2018 Oct 22;20(10):e10194 [FREE Full text] [doi: 10.2196/10194] [Medline: 30348626]

58. Sano A, Taylor S, McHill AW, Phillips AJ, Barger LK, Klerman E, et al. Identifying objective physiological markers and modifiable behaviors for self-reported stress and mental health status using wearable sensors and mobile phones: observational study. J Med Internet Res 2018 Jun 8;20(6):e210 [FREE Full text] [doi: 10.2196/jmir.9410] [Medline: 29884610]

59. di Matteo D, Fine A, Fotinos K, Rose J, Katzman M. Patient willingness to consent to mobile phone data collection for mental health apps: structured questionnaire. JMIR Ment Health 2018 Aug 29;5(3):e56 [FREE Full text] [doi:

10.2196/mental.9539] [Medline: $\underline{30158102]}$

60. Boonstra TW, Nicholas J, Wong QJ, Shaw F, Townsend S, Christensen H. Using mobile phone sensor technology for mental health research: integrated analysis to identify hidden challenges and potential solutions. J Med Internet Res 2018 Jul 30;20(7):e10131 [FREE Full text] [doi: 10.2196/10131] [Medline: 30061092]

61. Mohr DC, Lyon AR, Lattie EG, Reddy M, Schueller SM. Accelerating digital mental health research from early design and creation to successful implementation and sustainment. J Med Internet Res 2017 May 10;19(5):e153 [FREE Full text] [doi: 10.2196/jmir.7725] [Medline: 28490417]

62. Bidargaddi N, Musiat P, Winsall M, Vogl G, Blake V, Quinn S, et al. Efficacy of a web-based guided recommendation service for a curated list of readily available mental health and well-being mobile apps for young people: randomized controlled trial. J Med Internet Res 2017 May 12;19(5):e141 [FREE Full text] [doi: 10.2196/jmir.6775] [Medline: 28500020]

63. Grist R, Porter J, Stallard P. Mental health mobile apps for preadolescents and adolescents: a systematic review. J Med Internet Res 2017 May 25;19(5):e176 [FREE Full text] [doi: 10.2196/jmir.7332] [Medline: 28546138]

64. Rathbone AL, Prescott J. The use of mobile apps and SMS messaging as physical and mental health interventions: systematic review. J Med Internet Res 2017 Aug 24;19(8):e295 [FREE Full text] [doi: 10.2196/jmir.7740] [Medline: 28838887]

65. Mandryk RL, Birk MV. Toward game-based digital mental health interventions: player habits and preferences. J Med Internet Res 2017 Apr 20;19(4):e128 [FREE Full text] [doi: 10.2196/jmir.6906] [Medline: 28428161]

66. Bennett-Levy J, Singer J, DuBois S, Hyde K. Translating e-mental health into practice: what are the barriers and enablers to e-mental health implementation by aboriginal and Torres Strait Islander health professionals? J Med Internet Res 2017 Jan 11;19(1):e1 [FREE Full text] [doi: 10.2196/jmir.6269] [Medline: 28077347]

67. Berry N, Lobban F, Emsley R, Bucci S. Acceptability of interventions delivered online and through mobile phones for people who experience severe mental health problems: a systematic review. J Med Internet Res 2016 May 31;18(5):e121 [FREE Full text] [doi: 10.2196/jmir.5250] [Medline: 27245693]

68. Robotham D, Satkunanathan S, Doughty L, Wykes T. Do we still have a digital divide in mental health? A five-year survey follow-up. J Med Internet Res 2016 Nov 22;18(11):e309 [FREE Full text] [doi: 10.2196/jmir.6511] [Medline: 27876684]

69. Meurk C, Leung J, Hall W, Head BW, Whiteford H. Establishing and governing e-mental health care in Australia: a systematic review of challenges and a call for policy-focussed research. J Med Internet Res 2016 Jan 13;18(1):e10 [FREE Full text] [doi: 10.2196/jmir.4827] [Medline: 26764181]

70. Berrouiguet S, Baca-García E, Brandt S, Walter M, Courtet P. Fundamentals for future mobile-health (mhealth): a systematic review of mobile phone and web-based text messaging in mental health. J Med Internet Res 2016 Jun 10;18(6):e135 [FREE Full text] [doi: 10.2196/jmir.5066] [Medline: 27287668]

71. Kahn JR, Collinge W, Soltysik R. Post-9/11 veterans and their partners improve mental health outcomes with a self-directed mobile and web-based wellness training program: a randomized controlled trial. J Med Internet Res 2016 Sep 27;18(9):e255 [FREE Full text] [doi: 10.2196/jmir.5800] [Medline: 27678169]

72. Younes N, Chollet A, Menard E, Melchior M. E-mental health care among young adults and help-seeking behaviors: a transversal study in a community sample. J Med Internet Res 2015 May 15;17(5):e123 [FREE Full text] [doi: 10.2196/jmir.4254] [Medline: 25979680]

73. Torous J, Friedman R, Keshavan M. Smartphone ownership and interest in mobile applications to monitor symptoms of mental health conditions. JMIR Mhealth Uhealth 2014 Jan 21;2(1):e2 [FREE Full text] [doi: 10.2196/mhealth.2994] [Medline: 25098314]

74. Ellis LA, Collin P, Davenport TA, Hurley PJ, Burns JM, Hickie IB. Young men, mental health, and technology: implications for service design and delivery in the digital age. J Med Internet Res 2012 Nov 22;14(6):e160 [FREE Full text] [doi: 10.2196/jmir.2291] [Medline: 23171827]

75. Mohr DC, Duffecy J, Jin L, Ludman EJ, Lewis A, Begale M, et al. Multimodal e-mental health treatment for depression: a feasibility trial. J Med Internet Res 2010 Dec 19;12(5):e48 [FREE Full text] [doi: 10.2196/jmir.1370] [Medline: 21169164]

76. Bennett K, Bennett AJ, Griffiths KM. Security considerations for e-mental health interventions. J Med Internet Res 2010 Dec 19;12(5):e61 [FREE Full text] [doi: 10.2196/jmir.1468] [Medline: 21169173]

77. Mucic D, editor. E-Mental Health. Cham, UK: Springer; 2015. 
78. Shoemaker EZ, Hilty DM. E-mental health improves access to care, facilitates early intervention, and provides evidence-based treatments at a distance. In: E-Mental Health. Cham, UK: Springer; 2016:43-57.

79. Mucic D, Hilty DM, Yellowlees PM. E-Mental health toward cross-cultural populations worldwide. In: E-Mental health. Cham, UK: Springer; 2016:77-91.

80. Yellowlees PM, Hilty. DM, Mucic D. Global/worldwide e-mental health: international and futuristic perspectives of telepsychiatry and the future. In: E-mental health. Cham, UK: Springer; 2016:233-249.

81. Donald H, Barb J, Robert MM. How e-mental health adds to traditional outpatient and newer models of integrated care for patients, providers, and systems. In: E-Mental Health. Cham, UK: Springer; 2016:129-149.

82. Donald MH, Erica ZS, Jay S. How to build, evaluate, and increase your e-mental health program efficiency. In: E-Mental Health. Cham, UK: Springer; 2016:59-76.

83. Donald MH, Davor M. Technology, health, and contemporary practice: How does e-mental health fit it and what does it offer? In: E-Mental Health. Cham, UK: Springer; 2016:3-27.

84. Hilty DM, Yellowlees P, Myers K, Parish M, Rabinowitz T. The effectiveness of e-mental healthvidence base, how to choose the model based on ease/cost/strength, and future areas of research. In: E-mental Health. Cham, UK: Springer; 2016:95-127.

85. Clough BA, Zarean M, Ruane I, Mateo NJ, Aliyeva TA, Casey LM. Going global: do consumer preferences, attitudes, and barriers to using e-mental health services differ across countries? J Ment Health 2019 Feb;28(1):17-25. [doi: 10.1080/09638237.2017.1370639] [Medline: 28857650]

86. Kirst M, Pridham KF, Narrandes R, Matheson F, Young L, Niedra K, et al. Examining implementation of mobile, police-mental health crisis intervention teams in a large urban center. J Ment Health 2015 Dec;24(6):369-374. [doi: 10.3109/09638237.2015.1036970] [Medline: 26383041]

87. Ennis L, Rose D, Denis M, Pandit N, Wykes T. Can't surf, won't surf: the digital divide in mental health. J Ment Health 2012 Aug;21(4):395-403 [FREE Full text] [doi: 10.3109/09638237.2012.689437] [Medline: 22712756]

88. Musiat P, Hoffmann L, Schmidt U. Personalised computerised feedback in e-mental health. J Ment Health 2012 Aug;21(4):346-354. [doi: 10.3109/09638237.2011.648347] [Medline: 22315961]

89. Harrison V, Proudfoot J, Wee PP, Parker G, Pavlovic DH, Manicavasagar V. Mobile mental health: review of the emerging field and proof of concept study. J Ment Health 2011 Dec;20(6):509-524. [doi: 10.3109/09638237.2011.608746] [Medline: 21988230]

90. Berry N, Lobban F, Bucci S. A qualitative exploration of service user views about using digital health interventions for self-management in severe mental health problems. BMC Psychiatry 2019 Jan 21;19(1):35 [FREE Full text] [doi: 10.1186/s12888-018-1979-1] [Medline: 30665384]

91. Dreier M, Ludwig J, Härter M, von dem Knesebeck O, Baumgardt J, Bock T, et al. Development and evaluation of e-mental health interventions to reduce stigmatization of suicidality - a study protocol. BMC Psychiatry 2019 May 17;19(1):152 [FREE Full text] [doi: 10.1186/s12888-019-2137-0] [Medline: 31101103]

92. Metz MJ, Elfeddali I, Krol DG, Veerbeek MA, de Beurs E, Beekman AT, et al. A digital intake approach in specialized mental health care: study protocol of a cluster randomised controlled trial. BMC Psychiatry 2017 Mar 7;17(1):86 [FREE Full text] [doi: 10.1186/s12888-017-1247-9] [Medline: 28270129]

93. Agyapong VIO, Mrklas K, Juhás M, Omeje J, Ohinmaa A, Dursun SM, et al. Cross-sectional survey evaluating Text4Mood: mobile health program to reduce psychological treatment gap in mental healthcare in Alberta through daily supportive text messages. BMC Psychiatry 2016 Nov 8;16(1):378 [FREE Full text] [doi: 10.1186/s12888-016-1104-2] [Medline: 27821096]

94. Clarke J, Proudfoot J, Birch M, Whitton AE, Parker G, Manicavasagar V, et al. Effects of mental health self-efficacy on outcomes of a mobile phone and web intervention for mild-to-moderate depression, anxiety and stress: secondary analysis of a randomised controlled trial. BMC Psychiatry 2014 Sep 26;14:272 [FREE Full text] [doi: 10.1186/s12888-014-0272-1] [Medline: 25252853]

95. Krieger T, Meyer B, Sude K, Urech A, Maercker A, Berger T. Evaluating an e-mental health program ('deprexis') as adjunctive treatment tool in psychotherapy for depression: design of a pragmatic randomized controlled trial. BMC Psychiatry 2014 Oct 8;14:285 [FREE Full text] [doi: 10.1186/s12888-014-0285-9] [Medline: 25298158]

96. Musiat P, Goldstone P, Tarrier N. Understanding the acceptability of e-mental health--attitudes and expectations towards computerised self-help treatments for mental health problems. BMC Psychiatry 2014 Apr 11;14:109 [FREE Full text] [doi: 10.1186/1471-244X-14-109] [Medline: 24725765]

97. Ben-Zeev D, Buck B, Hallgren K, Drake RE. Effect of mobile health on in-person service use among people with serious mental illness. Psychiatr Serv 2019 Jun 1;70(6):507-510. [doi: 10.1176/appi.ps.201800542] [Medline: 30947636]

98. Fortuna KL, Walker R, Fisher DB, Mois G, Allan S, Deegan PE. Enhancing standards and principles in digital mental health with recovery-focused guidelines for mobile, online, and remote monitoring technologies. Psychiatr Serv 2019 Dec 1;70(12):1080-1081 [FREE Full text] [doi: 10.1176/appi.ps.201900166] [Medline: 31615369]

99. Torous J, Haim A. Dichotomies in the development and implementation of digital mental health tools. Psychiatr Serv 2018 Dec 1;69(12):1204-1206 [FREE Full text] [doi: 10.1176/appi.ps.201800193] [Medline: 30256182] 
100. Ben-Zeev D, Brian RM, Jonathan G, Razzano L, Pashka N, Carpenter-Song E, et al. Mobile health (mhealth) versus clinic-based group intervention for people with serious mental illness: a randomized controlled trial. Psychiatr Serv 2018 Sep 1;69(9):978-985. [doi: 10.1176/appi.ps.201800063] [Medline: 29793397]

101. Ben-Zeev D. Mobile health for mental health in West Africa: the case for Ghana. Psychiatr Serv 2018 Jul 1;69(7):741-743. [doi: 10.1176/appi.ps.201700555] [Medline: 29540120]

102. van der Krieke L, Wunderink L, Emerencia AC, de Jonge P, Sytema S. E-mental health self-management for psychotic disorders: state of the art and future perspectives. Psychiatr Serv 2014 Jan 1;65(1):33-49. [doi: 10.1176/appi.ps.201300050] [Medline: 24129842]

103. Iorfino F, Cross SP, Davenport T, Carpenter JS, Scott E, Shiran S, et al. A digital platform designed for youth mental health services to deliver personalized and measurement-based care. Front Psychiatry 2019;10:595 [FREE Full text] [doi: 10.3389/fpsyt.2019.00595] [Medline: $\underline{31507465]}$

104. Bucci S, Berry N, Morris R, Berry K, Haddock G, Lewis S, et al. 'They are not hard-to-reach clients. We have just got hard-to-reach services.' staff views of digital health tools in specialist mental health services. Front Psychiatry 2019;10:344 [FREE Full text] [doi: 10.3389/fpsyt.2019.00344] [Medline: 31133906 ]

105. Seifert A, Reinwand DA, Schlomann A. Designing and using digital mental health interventions for older adults: being aware of digital inequality. Front Psychiatry 2019;10:568 [FREE Full text] [doi: 10.3389/fpsyt.2019.00568] [Medline: $\underline{31447716}$ ]

106. Burchert S, Alkneme MS, Bird M, Carswell K, Cuijpers P, Hansen P, et al. User-centered app adaptation of a low-intensity e-mental health intervention for Syrian refugees. Front Psychiatry 2019;9:663 [FREE Full text] [doi: 10.3389/fpsyt.2018.00663] [Medline: $\underline{30740065]}$

107. Garrido S, Millington C, Cheers D, Boydell K, Schubert E, Meade T, et al. What works and what doesn't work? A systematic review of digital mental health interventions for depression and anxiety in young people. Front Psychiatry 2019;10:759 [FREE Full text] [doi: 10.3389/fpsyt.2019.00759] [Medline: 31798468]

108. Ebert DD, Cuijpers P, Muñoz RF, Baumeister H. Prevention of mental health disorders using internet- and mobile-based interventions: a narrative review and recommendations for future research. Front Psychiatry 2017;8:116. [doi: 10.3389/fpsyt.2017.00116] [Medline: 28848454]

109. Rehm IC, Foenander E, Wallace K, Abbott JM, Kyrios M, Thomas N. What role can avatars play in e-mental health interventions? Exploring new models of client-therapist interaction. Front Psychiatry 2016;7:186 [FREE Full text] [doi: 10.3389/fpsyt.2016.00186] [Medline: 27917128]

110. Bucci S, Ainsworth J, Barrowclough C, Lewis S, Haddock G, Berry K, et al. A theory-informed digital health intervention in people with severe mental health problems. Stud Health Technol Inform 2019 Aug 21;264:526-530. [doi: 10.3233/SHTI190278] [Medline: 31437979]

111. Househ M, Alam T, Al-Thani D, Schneider J, Siddig M, Fernandez-Luque L, et al. Developing a Digital Mental Health Platform for the Arab World: From Research to Action. 2019 Jul 04 Presented at: ICIMTH; July 2019; Athens, Greece p. 392-395 URL: http://ebooks.iospress.nl/publication/51763 [doi: 10.3233/SHTI190101]

112. Peyton D, Hiscock H, Sciberras E. Do digital health interventions improve mental health literacy or help-seeking among parents of children aged 2-12 years? A scoping review. Stud Health Technol Inform 2019 Aug 8;266:156-161. [doi: 10.3233/SHTI190788] [Medline: 31397317]

113. Strudwick G, Booth R, Strauss J. Identifying how patient portals may be effectively used among mental health populations to support digital inclusion: a study protocol. Stud Health Technol Inform 2018;250:30. [Medline: 29857361]

114. Wang J, Lam RW, Ho K, Attridge M, Lashewicz BM, Patten SB, et al. Preferred features of e-mental health programs for prevention of major depression in male workers: results from a Canadian national survey. J Med Internet Res 2016 Jun 6;18(6):e132 [FREE Full text] [doi: 10.2196/jmir.5685] [Medline: 27267782]

115. Perlich A, von Thienen J, Meinel C. Supporting talk-based mental health interventions with digital whiteboards. Stud Health Technol Inform 2014;205:433-437. [Medline: 25160221]

116. Naslund JA, Gonsalves PP, Gruebner O, Pendse SR, Smith SL, Sharma A, et al. Digital innovations for global mental health: opportunities for data science, task sharing, and early intervention. Curr Treat Options Psychiatry 2019 Dec;6(4):337-351. [doi: 10.1007/s40501-019-00186-8] [Medline: $\underline{32457823}$ ]

117. Boumparis N, Schulte MH, Riper H. Digital mental health for alcohol and substance use disorders. Curr Treat Options Psych 2019 Nov 26;6(4):352-366. [doi: 10.1007/s40501-019-00190-y]

118. Becker TD, Torous JB. Recent developments in digital mental health interventions for college and university students. Curr Treat Options Psych 2019 Jun 14;6(3):210-220. [doi: 10.1007/s40501-019-00178-8]

119. Wykes T, Lipshitz J, Schueller SM. Towards the design of ethical standards related to digital mental health and all its applications. Curr Treat Options Psych 2019 Jul 5;6(3):232-242. [doi: 10.1007/s40501-019-00180-0]

120. Schueller SM, Hunter JF, Figueroa C, Aguilera A. Use of digital mental health for marginalized and underserved populations. Curr Treat Options Psych 2019 Jul 5;6(3):243-255. [doi: 10.1007/s40501-019-00181-z]

121. Magee JC, Adut S, Brazill K, Warnick S. Mobile app tools for identifying and managing mental health disorders in primary care. Curr Treat Options Psychiatry 2018 Sep;5(3):345-362 [FREE Full text] [doi: 10.1007/s40501-018-0154-0] [Medline: 30397577] 
122. Johnson KF, Kalkbrenner MT. The utilization of technological innovations to support college student mental health: mobile health communication. J Tech Hum Serv 2017 Sep 11;35(4):314-339. [doi: 10.1080/15228835.2017.1368428]

123. East ML, Havard B, Hastings NB. Mental health mobile apps' instruction: technology adoption theories applied in a mixed methods study of counseling faculty. J Tech Hum Serv 2016 Oct 21;34(4):301-325. [doi: 10.1080/15228835.2016.1233842]

124. Mar MY, Neilson EK, Torchalla I, Werker GR, Laing A, Krausz M. Exploring e-mental health preferences of generation Y. J Tech Hum Serv 2014 Nov 26;32(4):312-327. [doi: 10.1080/15228835.2014.943457]

125. Feng XL, Campbell A. Understanding e-mental health resources: personality, awareness, utilization, and effectiveness of e-mental health resources amongst youth. J Tech Hum Serv 2011 Apr;29(2):101-119. [doi: 10.1080/15228835.2011.595276]

126. Zack JS. How sturdy is that digital couch? Legal considerations for mental health professionals who deliver clinical services via the internet. J Tech Hum Serv 2008 Jul 3;26(2-4):333-359. [doi: 10.1080/15228830802097083]

127. Marshall JM, Dunstan DA, Bartik W. Smartphone psychology: new approaches towards safe and efficacious mobile mental health apps. Prof Psychol Res Pr 2020 Jun;51(3):214-222. [doi: 10.1037/pro0000278]

128. Miller KE, Kuhn E, Yu J, Owen JE, Jaworski BK, Taylor K, et al. Use and perceptions of mobile apps for patients among VA primary care mental and behavioral health providers. Prof Psychol Res Pr 2019 Jun;50(3):204-209. [doi: $10.1037 /$ pro0000229]

129. Lui JH, Marcus DK, Barry CT. Evidence-based apps? A review of mental health mobile applications in a psychotherapy context. Prof Psychol Res Pr 2017 Jun;48(3):199-210. [doi: 10.1037/pro0000122]

130. Jones N, Moffitt M. Ethical guidelines for mobile app development within health and mental health fields. Professional Psychology: Research and Practice 2016 Apr;47(2):155-162 [FREE Full text] [doi: 10.1037/pro0000069]

131. Titov N, Dear BF, Staples LG, Bennett-Levy J, Klein B, Rapee RM, et al. The first 30 months of the MindSpot clinic: evaluation of a national e-mental health service against project objectives. Aust N Z J Psychiatry 2017 Dec;51(12):1227-1239. [doi: 10.1177/0004867416671598] [Medline: 27733709]

132. Batterham PJ, Sunderland M, Calear AL, Davey CG, Christensen H, Teesson M, et al. Developing a roadmap for the translation of e-mental health services for depression. Aust N Z J Psychiatry 2015 Sep;49(9):776-784. [doi: 10.1177/0004867415582054] [Medline: 25907269]

133. Christensen H, Petrie K. State of the e-mental health field in Australia: where are we now? Aust N Z J Psychiatry 2013 Feb;47(2):117-120. [doi: 10.1177/0004867412471439] [Medline: 23297367]

134. Jorm AF, Morgan AJ, Malhi GS. The future of e-mental health. Aust N Z J Psychiatry 2013 Feb;47(2):104-106. [doi: 10.1177/0004867412474076] [Medline: 23382504]

135. Strauss P, Morgan H, Toussaint DW, Lin A, Winter S, Perry Y. Trans and gender diverse young people's attitudes towards game-based digital mental health interventions: a qualitative investigation. Internet Interv 2019 Dec;18:100280 [FREE Full text] [doi: 10.1016/j.invent.2019.100280] [Medline: 31890628]

136. Apolinário-Hagen J, Fritsche L, Bierhals C, Salewski C. Improving attitudes toward e-mental health services in the general population via psychoeducational information material: a randomized controlled trial. Internet Interv 2018 Jun;12:141-149. [doi: 10.1016/j.invent.2017.12.002] [Medline: 30135778]

137. Schueller SM, Washburn JJ, Price M. Exploring mental health providers' interest in using web and mobile-based tools in their practices. Internet Interv 2016 May;4(2):145-151 [FREE Full text] [doi: 10.1016/j.invent.2016.06.004] [Medline: 28090438]

138. Hensel JM, Ellard K, Koltek M, Wilson G, Sareen J. Digital health solutions for indigenous mental well-being. Curr Psychiatry Rep 2019 Jul 1;21(8):68 [FREE Full text] [doi: 10.1007/s11920-019-1056-6] [Medline: 31263971 ]

139. Armontrout J, Torous J, Fisher M, Drogin E, Gutheil T. Mobile mental health: navigating new rules and regulations for digital tools. Curr Psychiatry Rep 2016 Oct;18(10):91. [doi: 10.1007/s11920-016-0726-X] [Medline: 27553979]

140. Torous J, Staples P, Onnela J. Realizing the potential of mobile mental health: new methods for new data in psychiatry. Curr Psychiatry Rep 2015 Aug;17(8):602 [FREE Full text] [doi: 10.1007/s11920-015-0602-0] [Medline: 26073363]

141. Zheng X, Woo BK. E-mental health in ethnic minority: a comparison of YouTube and talk-based educational workshops in dementia. Asian J Psychiatr 2017 Feb;25:246-248. [doi: 10.1016/j.ajp.2016.12.002] [Medline: 28262161]

142. Brian RM, Ben-Zeev D. Mobile health (mHealth) for mental health in Asia: objectives, strategies, and limitations. Asian J Psychiatr 2014 Aug;10:96-100. [doi: 10.1016/j.ajp.2014.04.006] [Medline: 25042960]

143. Aggarwal NK. Applying mobile technologies to mental health service delivery in South Asia. Asian J Psychiatr 2012 Sep;5(3):225-230. [doi: 10.1016/j.ajp.2011.12.009] [Medline: 22981050]

144. Orman J, Clarke J, Whittle E, Anonuevo C, Proudfoot J. A diabetes-specific e-mental health tool: development, acceptability and outcomes of a feasibility study. Aust Fam Physician 2016 Aug;45(8):600-605 [FREE Full text] [Medline: 27610452]

145. Orman J, O'Dea B, Shand F, Berk M, Proudfoot J, Christensen H. e-Mental health for mood and anxiety disorders in general practice. Aust Fam Physician 2014 Dec;43(12):832-837. [Medline: 25705730]

146. Reid SC, Kauer S, Khor A, Hearps S, Sanci L, Kennedy A, et al. Using a mobile phone application in youth mental health - an evaluation study. Aust Fam Physician 2012 Sep;41(9):711-714. [Medline: 22962650]

147. Punukollu M, Marques M. Use of mobile apps and technologies in child and adolescent mental health: a systematic review. Evid Based Ment Health 2019 Nov;22(4):161-166. [doi: 10.1136/ebmental-2019-300093] [Medline: 31358537] 
148. Sheehan R, Hassiotis A. Digital mental health and intellectual disabilities: state of the evidence and future directions. Evid Based Ment Health 2017 Nov;20(4):107-111. [doi: 10.1136/eb-2017-102759] [Medline: 28947677]

149. Davies EB, Craven MP, Martin JL, Simons L. Proportionate methods for evaluating a simple digital mental health tool. Evid Based Ment Health 2017 Nov;20(4):112-117 [FREE Full text] [doi: 10.1136/eb-2017-102755] [Medline: 28993317]

150. Damen K, Van DS. Virtual Reality as e-Mental Health to Support Starting with Mindfulness-Based Cognitive Therapy. In: International Conference on Entertainment Computing. 2018 Presented at: ICEC'18; September 18-20, 2018; Poznan, Poland. [doi: 10.1007/978-3-319-99426-0_24]

151. Chiou W, Kao C, Lo L, Huang D, Wang M, Chen B. Feasibility of Utilizing E-Mental Health with Mobile APP Interface for Social Support Enhencement: A Conceptional Solution for Postpartum Depression in Taiwan. In: International Conference of Design, User Experience, and Usability. 2017 Presented at: DUXU'17; July 9-14, 2017; Vancouver, Canada. [doi: 10.1007/978-3-319-58637-3 15]

152. Martinez SG, Badillo-Urquiola K, Leis R, Chavez J, Green T, Clements T. Investigation of Multimodal Mobile Applications for Improving Mental Health. In: International Conference on Augmented Cognition. 2016 Presented at: AC'16; July 17-22, 2016; Toronto, Canada. [doi: 10.1007/978-3-319-39952-2 32]

153. Fils-Aimé JR, Grelotti DJ, Thérosmé T, Kaiser BN, Raviola G, Alcindor Y, et al. A mobile clinic approach to the delivery of community-based mental health services in rural Haiti. PLoS One 2018;13(6):e0199313 [FREE Full text] [doi: 10.1371/journal.pone.0199313] [Medline: 29924866]

154. Sprenger M, Mettler T, Osma J. Health professionals' perspective on the promotion of e-mental health apps in the context of maternal depression. PLoS One 2017;12(7):e0180867 [FREE Full text] [doi: 10.1371/journal.pone.0180867] [Medline: 28704442]

155. Ketelaar SM, Nieuwenhuijsen K, Gärtner FR, Bolier L, Smeets O, Sluiter JK. Effect of an e-mental health approach to workers' health surveillance versus control group on work functioning of hospital employees: a cluster-RCT. PLoS One 2013;8(9):e72546 [FREE Full text] [doi: 10.1371/journal.pone.0072546] [Medline: 24069148]

156. Neilsen A, Wilson RL. Combining e-mental health intervention development with human computer interaction (HCI) design to enhance technology-facilitated recovery for people with depression and/or anxiety conditions: an integrative literature review. Int J Ment Health Nurs 2019 Feb;28(1):22-39. [doi: 10.1111/inm.12527] [Medline: 30133096]

157. de Vecchi N, Kenny A, Dickson-Swift V, Kidd S. How digital storytelling is used in mental health: a scoping review. Int J Ment Health Nurs 2016 Jun;25(3):183-193. [doi: 10.1111/inm.12206] [Medline: 26900000]

158. Lee SJ, Thomas P, Doulis C, Bowles D, Henderson K, Keppich-Arnold S, et al. Outcomes achieved by and police and clinician perspectives on a joint police officer and mental health clinician mobile response unit. Int J Ment Health Nurs 2015 Dec;24(6):538-546. [doi: 10.1111/inm.12153] [Medline: 26597480]

159. Naslund JA, Aschbrenner KA, Barre LK, Bartels SJ. Feasibility of popular m-health technologies for activity tracking among individuals with serious mental illness. Telemed J E Health 2015 Mar;21(3):213-216 [FREE Full text] [doi: 10.1089/tmj.2014.0105] [Medline: 25536190]

160. Chan S, Torous J, Hinton L, Yellowlees P. Towards a framework for evaluating mobile mental health apps. Telemed J E Health 2015 Dec;21(12):1038-1041. [doi: 10.1089/tmj.2015.0002] [Medline: 26171663]

161. Khasanshina EV, Wolfe WL, Emerson EN, Stachura ME. Counseling center-based tele-mental health for students at a rural university. Telemed J E Health 2008 Feb;14(1):35-41. [doi: 10.1089/tmj.2006.0038]

162. Torous J, Kossowsky J. Digital Mental Health for Youth: New Evidence but Still Much Unknown. Psychiatric Times. 2018. URL: https://www.psychiatrictimes.com/view/digital-mental-health-youth-new-evidence-still-much-unknown [accessed 2020-08-19]

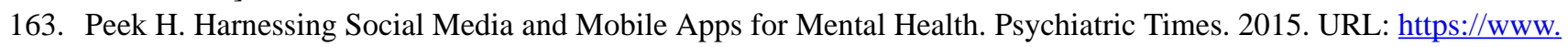
psychiatrictimes.com/view/harnessing-social-media-and-mobile-apps-mental-health [accessed 2020-08-19]

164. Brooks L, Schirmer T. Mobile Apps for Mental Health. Psychiatric Times. 2014. URL: https://www.psychiatrictimes.com/ view/mobile-apps-mental-health

165. Aschbrenner KA, Naslund JA, Tomlinson EF, Kinney A, Pratt SI, Brunette MF. Adolescents' use of digital technologies and preferences for mobile health coaching in public mental health settings. Front Public Health 2019;7:178 [FREE Full text] [doi: 10.3389/fpubh.2019.00178] [Medline: $\underline{\text { 31312629] }}$

166. Rojas G, Martínez V, Martínez P, Franco P, Jiménez-Molina A. Improving mental health care in developing countries through digital technologies: a mini narrative review of the Chilean case. Front Public Health 2019;7:391 [FREE Full text] [doi: 10.3389/fpubh.2019.00391] [Medline: 31921754]

167. Moock J. Support from the internet for individuals with mental disorders: advantages and disadvantages of e-mental health service delivery. Front Public Health 2014;2:65 [FREE Full text] [doi: 10.3389/fpubh.2014.00065] [Medline: 24967221]

168. Aryana B, Brewster L. Design for mobile mental health: exploring the informed participation approach. Health Informatics J 2019;26(2):1208-1224. [doi: 10.1177/1460458219873540] [Medline: 31566470]

169. Kenny R, Fitzgerald A, Segurado R, Dooley B. Is there an app for that? A cluster randomised controlled trial of a mobile app-based mental health intervention. Health Informatics J 2019;26(3):1538-1559. [doi: 10.1177/1460458219884195] [Medline: 31702409] 
170. Kenny R, Dooley B, Fitzgerald A. Developing mental health mobile apps: exploring adolescents' perspectives. Health Informatics J 2016 Jun;22(2):265-275. [doi: 10.1177/1460458214555041] [Medline: 25385165]

171. Sreejith G, Menon V. Mobile phones as a medium of mental health care service delivery: perspectives and barriers among patients with severe mental illness. Indian J Psychol Med 2019;41(5):428-433 [FREE Full text] [doi: 10.4103/IJPSYM.IJPSYM 333 18] [Medline: 31548765]

172. Basavarajappa C, Chand P. Digital platforms for mental health-care delivery. Indian J Psychol Med 2017;39(5):703-706 [FREE Full text] [doi: 10.4103/IJPSYM.IJPSYM_209_17] [Medline: 29200576]

173. Singh G, Manjunatha N, Rao S, Shashidhara H, Moirangthem S, Madegowda R, et al. Use of mobile phone technology to improve follow-up at a community mental health clinic: a randomized control trial. Indian J Psychol Med 2017;39(3):276-280 [FREE Full text] [doi: 10.4103/0253-7176.207325] [Medline: 28615760]

174. Graham AK, Lattie EG, Mohr DC. Experimental therapeutics for digital mental health. JAMA Psychiatry 2019 Aug 21:epub ahead of print. [doi: 10.1001/jamapsychiatry.2019.2075] [Medline: 31433448]

175. Torous J, Roberts LW. Needed innovation in digital health and smartphone applications for mental health: transparency and trust. JAMA Psychiatry 2017 May 1;74(5):437-438. [doi: 10.1001/jamapsychiatry.2017.0262] [Medline: 28384700]

176. Wynn SD, Sherrod RA. Providing mental health care to veterans in rural areas: using telehealth in mobile clinics. J Psychosoc Nurs Ment Health Serv 2012 Jun;50(6):22-28. [doi: 10.3928/02793695-20120508-01] [Medline: 22589227]

177. Tschirch P, Walker G, Calvacca LT. Nursing in tele-mental health. J Psychosoc Nurs Ment Health Serv 2006 May;44(5):20-27. [doi: 10.3928/02793695-20060501-05] [Medline: 16719184]

178. Sukmawati I, Ardi Z, Ifdil I, Zikra Z. Development and validation of acceptability of mental-health mobile app survey (AMMS) for android-based online counseling service assessment. J Phys: Conf Ser 2019 Dec 16;1339:012124. [doi: 10.1088/1742-6596/1339/1/012124]

179. Ardi Z, Sukmawati I, Ifdil I, Afdal A, Rangka IB, Suranata K. Exploring the acceptability of internet-based mental health mobile app services using network psychometrics analysis. J Phys: Conf Ser 2018 Dec 7;1114:012106. [doi: 10.1088/1742-6596/1114/1/012106]

180. Tielman ML, Neerincx MA, Pagliari C, Rizzo A, Brinkman W. Considering patient safety in autonomous e-mental health systems - detecting risk situations and referring patients back to human care. BMC Med Inform Decis Mak 2019 Mar 18;19(1):47 [FREE Full text] [doi: 10.1186/s12911-019-0796-x] [Medline: $\underline{\text { 30885190] }}$

181. Pelletier J, Rowe M, François N, Bordeleau J, Lupien S. No personalization without participation: on the active contribution of psychiatric patients to the development of a mobile application for mental health. BMC Med Inform Decis Mak 2013 Jul 27;13:78. [doi: 10.1186/1472-6947-13-78] [Medline: 23890085]

182. Williams A, Fossey E, Farhall J, Foley F, Thomas N. Going online together: the potential for mental health workers to integrate recovery oriented e-mental health resources into their practice. Psychiatry 2018;81(2):116-129. [doi: 10.1080/00332747.2018.1492852] [Medline: 30273103]

183. Morganstein J. Mobile applications for mental health providers. Psychiatry 2016;79(4):358-363. [doi: 10.1080/00332747.2016.1237753] [Medline: 27997318]

184. Rooksby J, Morrison A, Murray-Rust D. Student Perspectives on Digital Phenotyping: The Acceptability of Using Smartphone Data to Assess Mental Health. In: Proceedings of the 2019 CHI Conference on Human Factors in Computing Systems. 2019 Presented at: CHI'19; May 4-19, 2019; Glasgow, Scotland, UK. [doi: 10.1145/3290605.3300655]

185. Sakata J, Zhang M, Pu S, Xing J, Versha K. Beam: a Mobile Application to Improve Happiness and Mental Health. In: CHI '14 Extended Abstracts on Human Factors in Computing Systems. 2014 Presented at: CHI EA'14; April 26-May 1, 2014; Toronto, Canada. [doi: 10.1145/2559206.2580931]

186. Adewuya AO, Momodu O, Olibamoyo O, Adegbaju A, Adesoji O, Adegbokun A. The effectiveness and acceptability of mobile telephone adherence support for management of depression in the mental health in primary care (MeHPriC) project, Lagos, Nigeria: a pilot cluster randomised controlled trial. J Affect Disord 2019 Jun 15;253:118-125. [doi: 10.1016/j.jad.2019.04.025] [Medline: $\underline{\text { 31035212] }}$

187. Bakker D, Rickard N. Engagement in mobile phone app for self-monitoring of emotional wellbeing predicts changes in mental health: MoodPrism. J Affect Disord 2018 Feb;227:432-442. [doi: 10.1016/j.jad.2017.11.016] [Medline: 29154165]

188. Seko Y, Kidd S, Wiljer D, McKenzie K. Youth mental health interventions via mobile phones: a scoping review. Cyberpsychol Behav Soc Netw 2014 Sep;17(9):591-602. [doi: 10.1089/cyber.2014.0078] [Medline: 25007383]

189. Casey LM, Joy A, Clough BA. The impact of information on attitudes toward e-mental health services. Cyberpsychol Behav Soc Netw 2013 Aug;16(8):593-598. [doi: 10.1089/cyber.2012.0515] [Medline: 23679567]

190. Hendrikoff L, Kambeitz-Ilankovic L, Pryss R, Senner F, Falkai P, Pogarell O, et al. Prospective acceptance of distinct mobile mental health features in psychiatric patients and mental health professionals. J Psychiatr Res 2019 Feb;109:126-132. [doi: 10.1016/j.jpsychires.2018.11.025] [Medline: $\underline{30530207]}$

191. Wang K, Varma DS, Prosperi M. A systematic review of the effectiveness of mobile apps for monitoring and management of mental health symptoms or disorders. J Psychiatr Res 2018 Dec;107:73-78. [doi: 10.1016/j.jpsychires.2018.10.006] [Medline: $\underline{30347316}$ ] 
192. Schellong J, Lorenz P, Weidner K. Proposing a standardized, step-by-step model for creating post-traumatic stress disorder (PTSD) related mobile mental health apps in a framework based on technical and medical norms. Eur J Psychotraumatol 2019;10(1):1611090 [FREE Full text] [doi: 10.1080/20008198.2019.1611090] [Medline: 31143412 ]

193. Olff M. Mobile mental health: a challenging research agenda. Eur J Psychotraumatol 2015;6:27882 [FREE Full text] [doi: 10.3402/ejpt.v6.27882] [Medline: 25994025]

194. Teles A, Rodrigues I, Viana D, Silva F, Coutinho L, Endler M, et al. Mobile Mental Health: A Review of Applications for Depression Assistance. In: 32nd International Symposium on Computer-Based Medical Systems. 2019 Presented at: CBMS'19; June 5-7, 2019; Cordoba, Spain. [doi: 10.1109/cbms.2019.00143]

195. Teles AS, Silva F, Rocha A, Lopes J, O'Sullivan D, Van DV, et al. Towards Situation-Aware Mobile Applications in Mental Health. In: 29th International Symposium on Computer-Based Medical Systems. 2016 Presented at: CBMS'16; June 20-24, 2016; Dublin, Ireland. [doi: 10.1109/cbms.2016.7]

196. Gindidis S, Stewart S, Roodenburg J. A systematic scoping review of adolescent mental health treatment using mobile apps. Adv Mental Health 2019;17(2):161-177. [doi: 10.1080/18387357.2018.1523680]

197. Dragovic M, Davison S, Morgan VA, Chiu VW, Richards N, Vatskalis T, et al. 'Validated, easy to use and free': top three requests for mobile device applications ('apps') from mental health consumers and clinicians. Adv Mental Health 2018 Dec 11:1-9. [doi: 10.1080/18387357.2018.1557014]

198. Apolinário-Hagen J. Current perspectives on e-mental-health self-help treatments: Exploring the 'black box' Of public views, perceptions, and attitudes toward the digitalization of mental health care. In: The Digitization of Healthcare. London, UK: Palgrave Macmillan; 2017:205-223.

199. Eftychiou L, El Morr C. Mobile mental health virtual communities: challenges and opportunities. In: The Digitization of Healthcare. London, UK: Palgrave Macmillan; 2017:257-275.

200. Bakker D, Rickard N. Engagement with a cognitive behavioural therapy mobile phone app predicts changes in mental health and wellbeing: MoodMission. Aust Psychol 2019 Mar 13;54(4):245-260. [doi: 10.1111/ap.12383]

201. Dingwall KM, Puszka S, Sweet M, Nagel T. 'Like drawing into sand': acceptability, feasibility, and appropriateness of a new e-mental health resource for service providers working with aboriginal and Torres Strait Islander people. Aus Psychol 2015 Jan 12;50(1):60-69. [doi: 10.1111/ap.12100]

202. Cormode G, Krishnamurthy B. Key Differences Between Web 1.0 and Web 2.0. First Monday. 2008. URL: https:/ /firstmonday.org/ojs/index.php/fm/article/view/2125 [accessed 2020-08-19]

203. O'Reilly T. Web 2.0: Compact Definition? Radar - O'Reilly. 2005. URL: http://radar.oreilly.com/2005/10/ web-20-compact-definition.html [accessed 2020-04-30]

204. Murugesan S. Understanding Web 2.0. IEEE Computer Society. 2007. URL: https://www.computer.org/csdl/magazine/it/ 2007/04/f4034/13rRUyYSWoO [accessed 2020-08-19]

205. Number of Internet Users Worldwide From 2005 to 2019. Statista. 2020. URL: https://www.statista.com/statistics/273018/ number-of-internet-users-worldwide/

206. Number of Smartphones Sold to End Users Worldwide From 2007 to 2020. Statista. 2020. URL: https://www.statista.com/ statistics/263437/global-smartphone-sales-to-end-users-since-2007/

207. Share of Households That Use Desktop or Portable Computers to Access the Internet in Germany From 2003 to 2014. Statista. 2014. URL: https://www.statista.com/statistics/379251/internet-usage-via-desktop-or-mobile-computer-germany/ [accessed 2020-04-30]

208. Share of Households That Use Desktop or Portable Computers to Access the Internet in Portugal From 2003 to 2014. Statista. 2014. URL: https://www.statista.com/statistics/380431/internet-usage-via-desktop-or-mobile-computer-portugal/ [accessed 2020-04-30]

209. Share of Households That Use Desktop or Portable Computers to Access the Internet in Lithuania From 2003 to 2014. Statista. 2014. URL: https://www.statista.com/statistics/379295/internet-usage-via-desktop-or-mobile-computer-lithuania/ [accessed 2020-04-30]

210. Giannopoulos G. The application of information and communication technologies in transport. Eur J Oper Res 2004 Jan;152(2):302-320. [doi: 10.1016/s0377-2217(03)00026-2]

211. Buhalis D, O'Connor P. Information communication technology revolutionizing tourism. Tour Recreat Res 2015 Jan 12;30(3):7-16. [doi: 10.1080/02508281.2005.11081482]

212. Yusuf MO. Information and communication technology and education: analysing the Nigerian national policy for information technology. Int Educ J 2005;6(3):316-321 [FREE Full text]

213. Shachaf P. Cultural diversity and information and communication technology impacts on global virtual teams: An exploratory study. Information \& Management 2008 Mar;45(2):131-142. [doi: 10.1016/j.im.2007.12.003]

214. Shiferaw F, Zolfo M. The role of information communication technology (ICT) towards universal health coverage: the first steps of a telemedicine project in Ethiopia. Glob Health Action 2012;5:1-8 [FREE Full text] [doi: 10.3402/gha.v5i0.15638] [Medline: 22479235]

215. Kurtz MJ, Bollen J. Usage bibliometrics. Ann Rev Info Sci Tech 2012 Jan 18;44(1):1-64. [doi: 10.1002/aris.2010.1440440108]

216. Hicks D, Wouters P, Waltman L, de Rijcke S, Rafols I. Bibliometrics: the Leiden Manifesto for research metrics. Nature 2015 Apr 23;520(7548):429-431. [doi: 10.1038/520429a] [Medline: 25903611] 
217. Stephan P, Veugelers R, Wang J. Reviewers are blinkered by bibliometrics. Nature 2017 Apr 26;544(7651):411-412. [doi: 10.1038/544411a] [Medline: 28447652]

218. Haustein $\mathrm{S}$, Larivière V. The use of bibliometrics for assessing research: possibilities, limitations and adverse effects. In: Incentives and Performance. Cham, UK: Springer; 2015:121-139.

219. Agarwal A, Durairajanayagam D, Tatagari S, Esteves S, Harlev A, Henkel R, et al. Bibliometrics: tracking research impact by selecting the appropriate metrics. Asian J Androl 2016;18(2):296-309 [FREE Full text] [doi: 10.4103/1008-682X.171582] [Medline: 26806079]

220. Werner R. The focus on bibliometrics makes papers less useful. Nature 2015 Jan 15;517(7534):245. [doi: 10.1038/517245a] [Medline: 25592498]

221. Nickelson DW. Telehealth and the evolving health care system: strategic opportunities for professional psychology. Prof Psychol Res Pr 1998;29(6):527-535. [doi: 10.1037/0735-7028.29.6.527]

222. Alberta Heritage Foundation for Medical Research, Simpson J. An Assessment of Routine Telepsychiatry Services. Ponoka, Alberta: Alberta Heritage Foundation for Medical Research; 1999.

223. Della Mea V. What is e-health (2): the death of telemedicine? J Med Internet Res 2001;3(2):E22 [FREE Full text] [doi: 10.2196/jmir.3.2.e22] [Medline: 11720964]

224. Allen A. Morphing telemedicine-telecare-telehealth-ehealth. Telemed Today 2000;1(43):-

225. Number of Smartphone Users Worldwide From 2016 to 2021. Statista. 2020. URL: https://www.statista.com/statistics/ 330695/number-of-smartphone-users-worldwide/ [accessed 2020-04-30]

226. Emerging mHealth: Paths for Growth. PWC. 2014. URL: https:/www.pwc.com/gx/en/healthcare/mhealth/assets/ pwc-emerging-mhealth-full.pdf [accessed 2020-04-30]

227. Proudfoot J, Parker G, Hadzi Pavlovic D, Manicavasagar V, Adler E, Whitton A. Community attitudes to the appropriation of mobile phones for monitoring and managing depression, anxiety, and stress. J Med Internet Res 2010 Dec 19;12(5):e64 [FREE Full text] [doi: 10.2196/jmir.1475] [Medline: 21169174]

228. Drissi N, Ouhbi S, García-Berná J, Janati Idrissi MA, Ghogho M. Sensor-based Solutions for Mental Healthcare: A Systematic Literature Review. In: 13th International Conference on Health Informatics. 2020 Presented at: HEALTHINF'20; February 24-26, 2020; Valletta, Malta p. 593-600. [doi: 10.5220/0009100805930600]

229. Shewan LG, Coats AJ. Ethics in the authorship and publishing of scientific articles. Int J Cardiol 2010 Sep;144(1):1-2. [doi: 10.1016/j.ijcard.2010.07.030]

230. Ammenwerth E, de Keizer N. A viewpoint on evidence-based health informatics, based on a pilot survey on evaluation studies in health care informatics. J Am Med Inform Assoc 2007;14(3):368-371 [FREE Full text] [doi: 10.1197/jamia.M2276] [Medline: 17329724$]$

231. Sunitha S, Gururaj G. Health behaviours \& problems among young people in India: cause for concern \& call for action. Indian J Med Res 2014 Aug;140(2):185-208 [FREE Full text] [Medline: 25297351]

232. Stang J, Story M. Guidelines for Adolescent Nutrition Services. University of Minnesota. 2008. URL: https://books.google.ae/ books/about/Guidelines for Adolescent Nutrition Serv.html?id=t-zJDAEACAAJ\&redir esc=y

233. Garber J, Frankel SA, Herrington CG. Developmental demands of cognitive behavioral therapy for depression in children and adolescents: cognitive, social, and emotional processes. Annu Rev Clin Psychol 2016;12:181-216 [FREE Full text] [doi: 10.1146/annurev-clinpsy-032814-112836] [Medline: 27019397]

234. Nalwa K, Anand AP. Internet addiction in students: a cause of concern. Cyberpsychol Behav 2003 Dec;6(6):653-656. [doi: 10.1089/109493103322725441] [Medline: 14756932]

235. Young K, Pistner M, O'Mara J, Buchanan J. Cyber disorders: the mental health concern for the new millennium. Cyberpsychol Behav 1999;2(5):475-479. [doi: 10.1089/cpb.1999.2.475] [Medline: 19178220]

236. Depression and Other Common Mental Disorders: Global Health Estimates. World Health Organization. 2017. URL: https:/ lapps.who.int/iris/bitstream/handle/10665/254610/WHO-MSD-MER-2017.2-eng.pdf

237. Fonseca A, Gorayeb R, Canavarro MC. Women's use of online resources and acceptance of e-mental health tools during the perinatal period. Int J Med Inform 2016 Oct;94:228-236. [doi: 10.1016/j.ijmedinf.2016.07.016] [Medline: 27573331]

238. Kim J, Lim S, Lee B, Lee J. Detecting Depression of Cancer Patients with Daily Mental Health Logs from Mobile Applications. Association for Information Systems (AIS) eLibrary. 2015. URL: https://aisel.aisnet.org/cgi/viewcontent. cgi? article $=1551 \&$ context $=$ icis2015 [accessed 2020-08-19]

239. Drissi N, Ouhbi S, Janati Idrissi MA, Ghogho M. Mobile Apps for Post Traumatic Stress Disorder. In: Conf Proc IEEE Eng Med Biol Soc. 2019 Jul Presented at: EMBC'19; July 23-27, 2019; Berlin, Germany p. 4279-4282 URL: https:/ lieeexplore.ieee.org/abstract/document/8857197 [doi: 10.1109/EMBC.2019.8857197]

240. Excellence in Research for Australia. Australian Research Council. 2019. URL: https://www.arc.gov.au/ excellence-research-australia [accessed 2020-04-30]

241. Research Opportunities. Australian Government. 2020. URL: https://www.studyinaustralia.gov.au/English/ Australian-Education/Universities-Higher-Education/research-opportunities

242. About the Australasian Institute of Digital Health. Australasian Institute of Digital Health. 2020. URL: https://digitalhealth. org.au/about/ [accessed 2020-04-30] 
243. Hather GJ, Haynes W, Higdon R, Kolker N, Stewart EA, Arzberger P, et al. The United States of America and scientific research. PLoS One 2010 Aug 16;5(8):e12203 [FREE Full text] [doi: 10.1371/journal.pone.0012203] [Medline: 20808949]

244. 50 Leaders in Health IT. Becker's Hospital Review - Healthcare News. 2015. URL: https://www.beckershospitalreview.com/ healthcare-information-technology/50-leaders-in-health-it.html [accessed 2020-04-30]

245. Hashemi B, Ali S, Awaad R, Soudi L, Housel L, Sosebee SJ. Facilitating mental health screening of war-torn populations using mobile applications. Soc Psychiatry Psychiatr Epidemiol 2017 Jan;52(1):27-33. [doi: 10.1007/s00127-016-1303-7] [Medline: 27815623]

246. Phillips EA, Gordeev VS, Schreyögg J. Effectiveness of occupational e-mental health interventions: a systematic review and meta-analysis of randomized controlled trials. Scand J Work Environ Health 2019 Nov 1;45(6):560-576. [doi: 10.5271/sjweh.3839] [Medline: 31184758]

247. Richardson LK, Frueh BC, Grubaugh A, Egede L, Elhai J. Current directions in videoconferencing tele-mental health research. Clin Psychol (New York) 2009 Sep 1;16(3):323-338 [FRE Full text] [doi: 10.1111/j.1468-2850.2009.01170.x] [Medline: 20161010]

248. 249 AD, Sivertsen G. A criteria-based assessment of the coverage of Scopus and web of science. J Data Inf Sci 2019;4(1):1-21. [doi: 10.2478/jdis-2019-0001]

249. Karampela M, Ouhbi S, Isomursu M. Personal health data: a systematic mapping study. Int J Med Inform 2018 Oct;118:86-98. [doi: 10.1016/j.ijmedinf.2018.08.006] [Medline: 30153927]

250. Souza-Pereira L, Pombo N, Ouhbi S, Felizardo V, Garcia N. Clinical decision support systems for chronic diseases: a systematic literature review. Comput Methods Programs Biomed 2020 May 23;195:105565. [doi: $\underline{10.1016 / j . c m p b .2020 .105565]}$ [Medline: $\underline{\text { 32480191] }}$

\author{
Abbreviations \\ CMH: connected mental health \\ COVID-19: coronavirus disease \\ EC: exclusion criteria \\ e-mental: electronic mental \\ ICT: information and communication technologies \\ m-mental: mobile mental \\ MQ: mapping question \\ RCTs: randomized control trials \\ WoS: Web of Science
}

Edited by T Rashid Soron; submitted 07.05.20; peer-reviewed by S Chen, S Brigitte, P Matthews, D Hidalgo-Mazzei; comments to
author 14.06.20; revised version received 02.07.20; accepted 28.07.20; published 28.08.20
Please cite as:
Drissi N, Ouhbi S, Janati Idrissi MA, Fernandez-Luque L, Ghogho M
Connected Mental Health: Systematic Mapping Study
J Med Internet Res 2020;22(8):e19950
URL: http://www.jmir.org/2020/8/e19950/
doi: $10.2196 / 19950$
PMID: $\underline{32857055}$

CNidal Drissi, Sofia Ouhbi, Mohammed Abdou Janati Idrissi, Luis Fernandez-Luque, Mounir Ghogho. Originally published in the Journal of Medical Internet Research (http://www.jmir.org), 28.08.2020. This is an open-access article distributed under the terms of the Creative Commons Attribution License (https://creativecommons.org/licenses/by/4.0/), which permits unrestricted use, distribution, and reproduction in any medium, provided the original work, first published in the Journal of Medical Internet Research, is properly cited. The complete bibliographic information, a link to the original publication on http://www.jmir.org/, as well as this copyright and license information must be included. 